\title{
The Palaeoproterozoic Grythyttan Field in the Svecofennian Orogen, West Bergslagen, Central Sweden: structure, stratigraphy and age
}

\author{
Gerrit Kuipers ${ }^{1}$, Frank F. Beunk ${ }^{2}$, Keewook $\mathrm{Yi}^{3}$ \& Frederik M. van der Wateren ${ }^{4}$ \\ ${ }^{1}$ Stroom 171, 9406 EL Assen, the Netherlands. \\ ${ }^{2}$ Vrije Universiteit Amsterdam, Department of Earth Sciences, De Boelelaan 1085, 1081 HV Amsterdam, the Netherlands. \\ ${ }^{3}$ Division of Earth and Environmental Sciences, Korean Basic Science Institute, Ochang 363-833, Korea. \\ ${ }^{4}$ Cas Oorthuyskade 23, 1087 DP Amsterdam, the Netherlands. \\ E-mail corresponding author (Frank F. Beunk): frank.beunk@vu.nl
}

A number of discrete slate belts of limited size occur in the Palaeoproterozoic volcano-sedimentary Bergslagen Group of western Bergslagen in the Fennoscandian Shield of south-central Sweden. The Grythyttan Slate Belt (GSB), studied for more than a century, forms a single basin with the nearby Saxån Slate Belt (SSB). We use the lithostratigraphy of the Grythyttan Slate Formation of the Grythyttan belt, based on basin-scale sedimentary facies associations of the volcaniclastic sediments in time and space, as a method to interpret overall tectonic structure. Contrary to traditional views, we reconstruct the GSB as a single overturned limb of a $\mathrm{km}$-scale anticline with horizontal axis in the hanging wall of an east-vergent thrust fault, reactivating a listric extensional fault. The fold connects the GSB to the neighboring SSB. Folding and thrusting were related to tectonic closure of a volcanic back-arc or intra-arc basin. The early folds were subsequently affected by strike-slip shearing and folding around vertical fold axes, which partitioned preferentially into the least competent lithologies (slates and marbles), significantly modifying the map appearance of the slate belt. The late shearing and folding resulted from accretion of Bergslagen onto the Fennoscandian continental margin during the late, Svecobaltic phase of the Svecofennian orogeny. The GSB forms a thin, intraformational wedge in the Bergslagen Group and represents a relatively short interlude with a conglomeratic alluvial fan and turbiditic volcaniclastics followed by more felsic volcanic rocks resembling those of the Bergslagen Group. We suggest that the GSB, and by inference the other slate belts, stem from calderas, as either terrestrial volcanic lakes or shallow submarine eruption centres. The conglomerates are pre-orogenic, not a post-orogenic molasse as traditionally conceived, and their clast fabric has resulted from sedimentary processes only. Newly determined SIMS U-Pb zircon ages constrain the age of the GSB at c. $1895 \mathrm{Ma}$.

Keywords: Palaeoproterozoic, structure, stratigraphy, geochronology, Bergslagen, Sweden

Received 4. January 2018 / Accepted 15. May 2018 / Published online 14. September 2018

\section{Introduction}

The Grythyttan Field (GF) in the western Bergslagen region of south-central Sweden is located in the southwestern part of the 1.9-1.8 Ga Svecofennian (also referred to as Svecokarelian) Orogen of the Fennoscandian Shield (Fig. 1). It derives its name from the study of Sundius (1923), and is approximately equivalent to a c. 25 by $40 \mathrm{~km}$ large enclave of volcanosedimentary, low-grade, greenschist-facies rocks amidst their higher grade equivalents to the east and west (Stephens et al., 2007). Alternatively, the suite has been called the Bergslagen Supracrustal Series (Oen et al., 1982; note chronostratigraphic nomenclature used for lithostratigraphy!), or the Bergslagen Group (Beunk \& Kuipers, 2012). It extends predominantly through western and southern Bergslagen, but sheets of the supracrustal rocks are exposed in central Bergslagen as well, amidst an abundance of cogenetic and coeval intrusive rocks, viz. a bimodal, pre-tectonic Granitoid- 


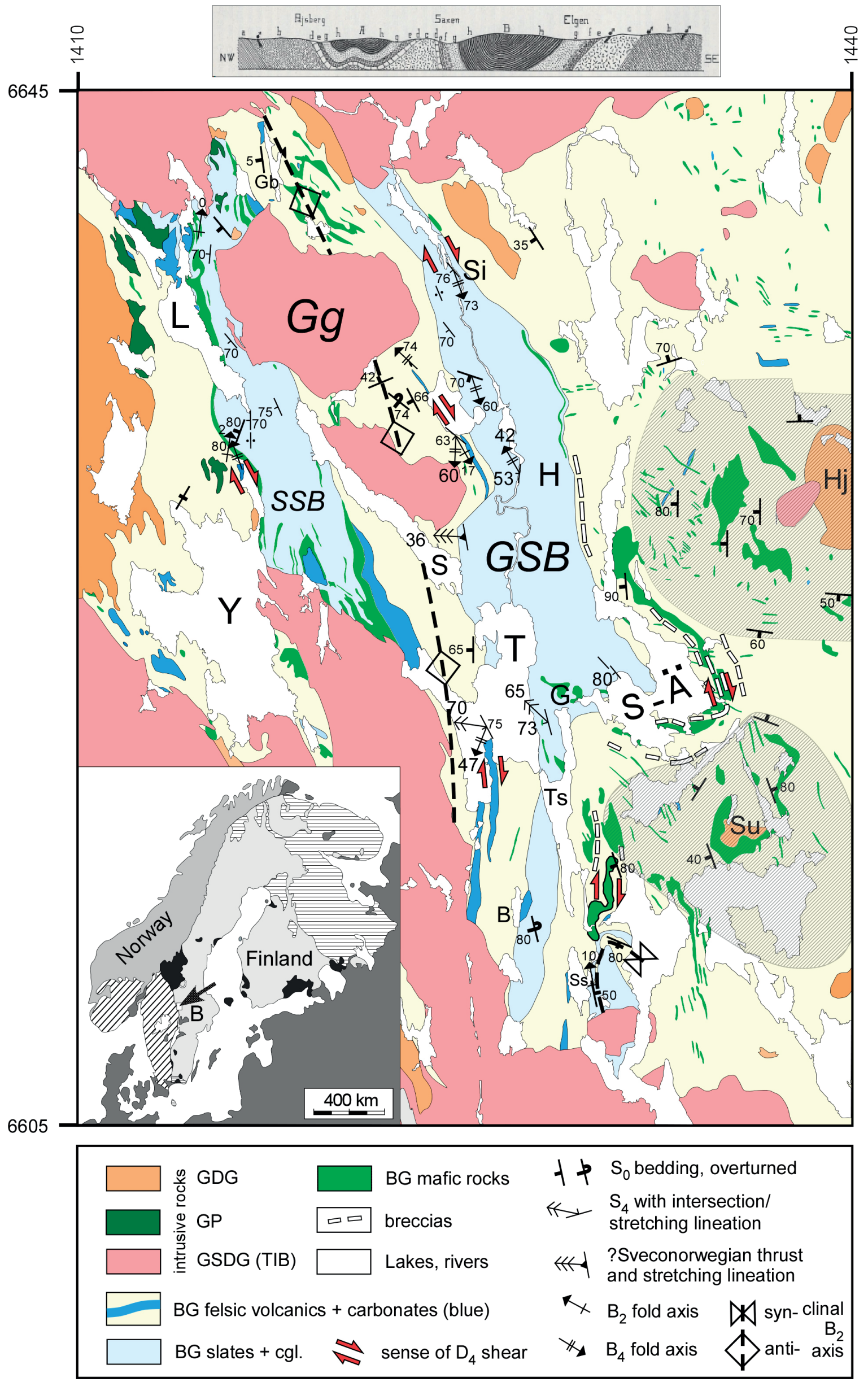


Dioritoid-Gabbroid suite (GDG; Stephens et al., 2009), Figs. 1 and 2. Stephens and coauthors summarised available geochronological data for the Bergslagen Group (1.91-1.89 Ga) and GDG intrusions (1.91-1.88 $\mathrm{Ga})$. Younger, late- and post-Svecokarelian intrusions comprise the 1.87-1.84 Ga old GSDG suite (GraniteSyenitoid-Dioritoid-Gabbroid) and the $1.85-1.75 \mathrm{Ga}$ old GP suite (Granite-Pegmatite). A younger subgroup of GSDG rocks in westernmost Bergslagen, 1.81-1.76 Ga in age, is equivalent to the Transscandinavian Igneous Belt (TIB) which straddles the N-S-trending, Neoproterozoic, Sveconorwegian Deformation Front in southern Sweden (Fig. 1); locally, they are known as the $1.78 \mathrm{Ga}$ old Filipstad granites (Fig. 2). The volcanic rocks of the BG and their intrusive equivalents are bimodal felsic/mafic, but dominantly felsic. Högbom (1910) described western Bergslagen as the leptite region, after the predominance of the low-grade, fine-grained, felsic volcan(iclast)ic rocks. The supracrustal suite is renowned and has been exploited since the Middle Ages for a great variety of ore deposits, mainly banded iron formations and various base-metal sulphide ores (Stephens et al., 2009).

Figure 1. Geological map, $30 \times 40 \mathrm{~km}$, of the Palaeoproterozoic bedrock in the Grythyttan Field and surrounding areas in west Bergslagen, with the Grythyttan (GSB) and Saxain (SSB) slate belts, after Björk (1983), Lundegård \& Bygghammar (1987), Lundström (1995b) and Wiklander \& Lundström (1991). Structural data updated after Beunk \& Kuipers (2012). Abbrevations: B - lake Brunnsjön, G - Grythyttan, Gb - Gåsborn, Gg - Gåsborn granite, $H$ - Hällefors, $H j$ - centre of Hjulsjö volcano, $L$ - lake Långban, $S$ - lake Saxen, S- ̈̈ - lake Sör-Älgen, Si - Silvergruvan, Ss - lake Sirsjön, Su - centre of Sundsjö volcano, T - lake Torrvarpen, Ts lake South Torrvarpen, $Y$ - lake Yngen. Acronyms in legend: $B G$ - Bergslagen Group; intrusive rocks series, named after Stephens et al., 2009: GDG - Granitoid-Dioritoid-Gabbroid, GP - GranitePegmatite, GSDG - Granite-Syenitoid-Dioritoid-Gabbroid, TIB Transscandinavian Igneous Belt. The southern part of the GSB, east of Lake Brunnsjön (B), contains a thick conglomerate unit. Locally, to the west of Hällefors, the western boundary of the GSB is a c. $40^{\circ}$ $W$-dipping, E-vergent Sveconorwegian thrust (Wahlgren \& Stephens, 1990; Lundström, 1995b). Two diagonally hatched, subcircular areas along the eastern map border ( $\mathrm{Hj}, \mathrm{Su})$ are granite-granophyre cored volcano-plutonic complexes, after Van der Velden et al. (1982) and Van Meerten (1988). Locations of regional sub-horizontal axes of $B_{2}$ anti- and synclinoria are approximate. Map-scale $F_{4}$ folds with subvertical axes originating from right-lateral $D_{4}$ shearing (Beunk \& Kuipers, 2012) occur along lake Sör-Älgen and in a slate-sandstone syncline directly east of lake Sirsjön, as well as in the Z-shaped mafic body directly to its north (thick outline). Stratigraphic way-up directions can be observed in places in the field but have not been added to the map, since intense small-scale folding greatly reduces their usability for the overall structural interpretation. RT90 2.5 gon $V$ coordinates used here and in subsequent figures. Inset (lower left), showing location of main map (arrowed): Horizontal ruling - Archaean cratons; light grey - Palaeoproterozoic Svecofennian orogen; black - Mesoproterozoic intrusions; diagonal ruling Neoproterozoic Sveconorwegian (Grenvillian) orogen; medium grey - Caledonian orogen; dark grey - Phanerozoic cover; B - Bergslagen. The $b \& w$ inset above the map is Högbom's (1910) E-W profile across the SSB and GSB at mid-latitude.
The Grythyttan Field has been studied repeatedly, because of its low metamorphic grade and optimal preservation of primary characteristics of the volcanosedimentary succession. The geology of the Grythyttan Field is of historical importance following the monograph by Högbom (1910) and the thesis work of Sundius (1923). For most of the twentieth century it served as a standard for the interpretation of the supracrustal geology, not only of the areally restricted Grythyttan Field, but even of Bergslagen as a whole. Central to the GF is a volcaniclastic metasedimentary belt, called the Grythyttan Slate Belt (GSB; Fig. 1) by Beunk \& Kuipers (2012), one of a small number of similar, restricted and isolated slate belts in western Bergslagen. The GSB stretches over c. $32 \mathrm{~km}$ in N-S direction and is up to $5 \mathrm{~km}$ wide. About $5 \mathrm{~km}$ to the west, the 20 by $3 \mathrm{~km}$ Saxån Slate Belt (SSB; Fig. 1) parallels the GSB. Lithologically, the GSB differs substantially from the surrounding metavolcanic rocks of the Bergslagen Group. It has three dominant lithologies: grey slates, black carbonaceous slates, and conglomerates. Kuipers (1987) identified the grey slates as volcaniclastic turbidites. The conglomeratic member consists of sandy and silty siliciclastics, interspersed with intrabasinal conglomeratic lenses, and was interpreted as an alluvial fan by Kuipers \& Beunk (2014). The GSB displays a pronounced lateral lithological variation: grey slates in the north give way to black slates in the centre, and to the alluvial fan in the south (Fig. 2). Sundius (1923) interpreted the GSB with its prominent conglomeratic member - unique among the regional slate belts - as the late-orogenic erosional molasse of the Svecofennian orogeny and, consequently, assigned it to the top of the Svecofennian supracrustal lithostratigraphy. Confusingly, his structural profiles across the GF follow Högbom (1910), in depicting the GSB as a pre-orogenic, synclinorially infolded, sedimentary sequence (inset Fig. 1). Subsequent authors (Oen et al., 1982; Lundström, 1987; Kuipers, 1987; Oen, 1987) follow Sundius in assigning the GSB to the top of the supracrustal series. Oen et al., (1982) envisaged deposition of the GSB in a newly developed rift basin after an initial shortening of the basin which accommodated their Bergslagen Supracrustal Series. Similarly, Lundström (1987) noted the presence of an unconformity separating conglomerates in the southern part of the GSB from underlying metavolcanic rocks and marbles. Later on, after a remapping of the area in the 1980s by the Swedish Geological Survey, Wiklander \& Lundström (1991) interpreted all contacts of the conglomeratic member as faulted, leaving its stratigraphic relationship to the main part of the GSB and to the surrounding metavolcanic rocks of the Bergslagen Group uncertain. Finally, Beunk \& Kuipers (2012) suggested that the GSB and the SSB constitute a basin superimposed onto and post-dating the Bergslagen Group, in a tectonic and temporal framework summarised in the next section. In their paper, the GSB served as an indicator for a major tectonic phase of the accretional tectonic evolution of the southwestern part of the Svecofennian orogen. 
This summary illustrates the present stage of uncertainty and disagreement regarding the age of the GSB, its structure and internal lithostratigraphy, as well as its lithostratigraphic and structural relationship to the surrounding metavolcanic rocks of the Bergslagen Group, and, ultimately, its relevance for Svecofennian orogenic (accretional) evolution. These various issues warrant our new study of the historical subject in order to clarify the stratigraphic, structural and tectonic problems by reconsideration of former interpretations, supported by new field observations, and by a zircon U$\mathrm{Pb}$ geochronological study of volcanic members of the GSB itself and of its volcanic basement.

\section{Structural setting of the Grythyttan Field in the Svecofennian Orogen}

Geochronological data and deep seismic sounding along several profiles have greatly advanced our knowledge about the structure and temporal and tectonic evolution of the Svecofennian Orogen. As a result, the orogen is now widely recognised as an accretionary collage of microcontinents and island arcs (e.g., Korja et al., 2006). Lahtinen et al. (2005) subdivided the Svecofennian into two separate orogenies, a 1.89-1.87 Ga Fennian in the northeast of the Fennoscandian Shield and a later Svecobaltic orogeny in the southwest, including Bergslagen, at 1.83-1.79 Ga. The nature of the accretionary processes of Bergslagen remains disputed, however. Stephens et al. (2009) and Hermansson et al. (2008) proposed in situ outgrowth of Bergslagen crust along the southwestern Svecofennian continental margin above a retreating subduction zone. Beunk \& Kuipers (2012) on the other hand interpret Bergslagen as a Svecobaltic accreted microcontinent.

Petrology and geochemistry of the magmatic rock series of Bergslagen, and its ore geology, support the generally accepted interpretation of their initial tectonic setting as a continental margin magmatic arc, or rather a rifted arc or back-arc basin (e.g., Beunk \& Valbracht, 1991; Allen et al., 1996; Stephens et al., 2009). In the tectonic scheme of Beunk \& Kuipers (2012), arc extension ( $D_{1}$ ) shifted to back-arc shortening $\left(\mathrm{D}_{2}\right)$, before $\mathrm{D}_{3}$ separation of the Bergslagen microcontinental ribbon. $\mathrm{D}_{4}$ accretion onto the Fennoscandian continental margin converted the narrow Bergslagen microcontinent into a double, S-shaped orocline, totalling some $700 \mathrm{~km}$ in length, folded along vertical fold axes. The GF is located in the northwestern hinge zone of the S-shaped belt. The oroclines also define the eastward bulge of the Swedish Baltic coast (inset Fig. 1). The $\mathrm{F}_{4}$ folds with vertical axes resulting from oroclinal bending - hereafter called 'vertical folds' - present on all scales from the 1:1.000.000 map to outcrop and thin-section, are a key element of the accretional model of Beunk \& Kuipers
(2012), and cannot easily be explained otherwise. The $\mathrm{F}_{4}$ folds refolded earlier tight horizontal $\mathrm{F}_{2}$ folds, i.e., folds with horizontal axes. In the past, lack of recognition of superimposed vertical folding had seriously hampered our understanding of the geology, on local as well as regional scales. Syn-accretional N-S shortening $\left(D_{4}\right)$ also gave rise to conjugate shear systems in Bergslagen. Shearing preferentially partitioned into incompetent lithologies, particularly the marbles and slate belts. The N-S to NW-SE-striking GSB and SSB provide excellent examples of $\mathrm{D}_{4}$ shearing, as right-lateral conjugates to left-lateral shear in NE-SW-striking marble and slate belts farther east (see Beunk \& Kuipers, 2012). The peculiar shape of the GSB, bulging to the east along lake Sör-Älgen (Fig. 1) and herein called the Sör-Älgen fold, reflects a disharmonic, Z-shaped, vertical, right-lateral, $\mathrm{F}_{4}$ shear fold with a strongly thickened hinge containing intricately folded slates.

Beunk \& Kuipers (2012) tentatively equated the sediments of the GSB and SSB to deposition in an extensional $\mathrm{D}_{3}$-basin superimposed onto the Bergslagen Group metavolcanic rocks, formed at around $1.85 \mathrm{Ga}$, postdating earlier compressive closure of the backarc basin ( $\mathrm{D}_{2}$ in their framework), but predating final accretion and oroclinal deformation $\left(\mathrm{D}_{4}, \leq 1.83 \mathrm{Ga}\right)$. Their reasoning was based on (i) the contrasting lithologies of the slate belts and the metavolcanic Bergslagen Group, the former containing debris apparently derived from the latter, (ii) the presence of only a single metamorphic foliation in the GSB, in contrast to neighbouring higher-grade parts of the Bergslagen Group, and (iii) on the presence of a synsedimentary fault, refolded by $\mathrm{F}_{4}$, between the GSB and the metavolcanic rocks of the $\mathrm{BG}$ to the east. The $\mathrm{D}_{3}$ interpretation and derived $1.85 \mathrm{Ga}$ age of sedimentation of the Bergslagen Group of Beunk \& Kuipers (2012) will be critically assessed in the present paper.

\section{Stratigraphy}

In western Bergslagen, the Bergslagen Group is characterised by the occurrence of volcanogenic sedimentary rocks in a shallow-marine and locally subaerial environment: carbonate units, locally stromatolitic (Boekschoten et al., 1988), occur in all stratigraphic divisions. However, the slate belts consist mainly of relatively deep-water sediments, like distal turbidites (Kuipers, 1987). Sundius (1923) subdivided the leptites (or 'hälleflintas') of western Bergslagen into two subgroups, a lower division (sodium-rich rocks rich in albite) and an upper division (potassium-rich) stratigraphically following concordantly above the former; see Table 1. The potassic and sodic nature was later shown to have a secondary origin related to the temperature (and hence depth) of hydrothermal sub-seafloor rock-seawater 


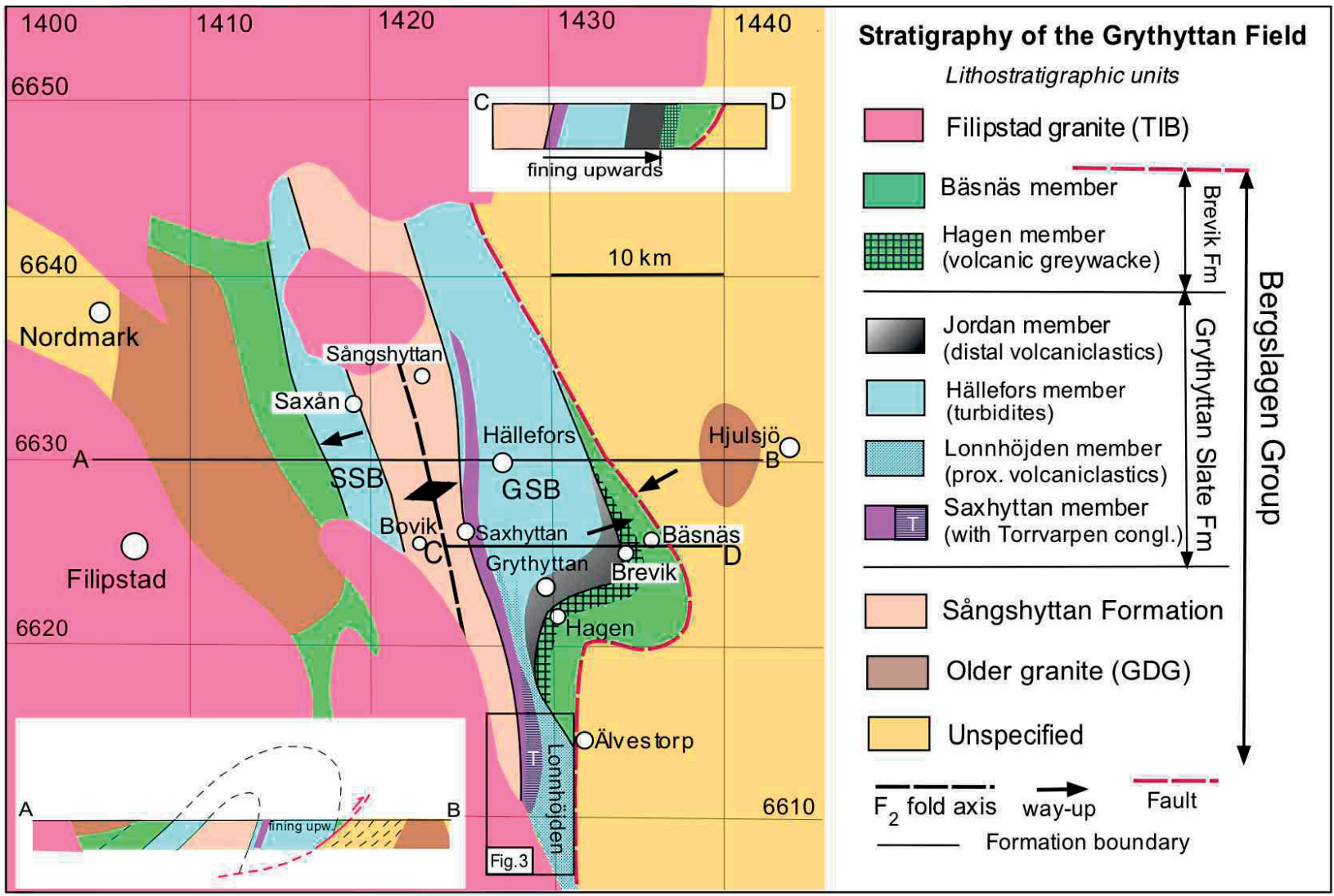

Figure 2. Schematic geological map of the Grythyttan-Saxån Field, showing distribution of the lithostratigraphic facies as defined in this paper, with cross sections $A-B$ and $C-D$ showing the structural relationship between the Grythyttan and the Saxan slate belts, in map and profile. The fault along the eastern border of the GSB is interpreted as a listric extensional $D_{1}$ fault, reactivated as a $D_{2}$ thrust. Thickening of the slates in the $G S B$, the eastern limb of the large central $F_{2}$ anticlinorium (first phase of folding), is an effect of subsequent $D_{4}$ strike-slip shear (in line of sight in the profiles) and disharmonic folding of the second, $F_{4}$ phase. See text for further explanation. Profile A-B intersects horizontal $B_{2} f o l d$ axes, while the map serves as a profile of the vertical $F_{4}$ folding. Profile A-B neglects local Sveconorwegian east-vergent thrusting along the western margin of the GSB at the latitude of Hällefors (Wiklander \& Lundström, 1991).

Table 1. Lithostratigraphic divisions of the Grythyttan Field, from Sundius (1923), Oen (1987) and as proposed herein. Lateral facies relationships are shown in Fig. 6.

\begin{tabular}{|c|c|c|c|c|}
\hline \multirow{2}{*}{$\begin{array}{l}\text { Proposed here } \\
\text { Brevik Fm }\end{array}$} & \multicolumn{2}{|c|}{ Grythyttan Slate Belt } & \multirow[t]{2}{*}{ Oen 1987} & \multirow[t]{2}{*}{ Sundius 1923} \\
\hline & Bäsnäs Mb: & $\begin{array}{l}\text { Bedded acid volcaniclastics and } \\
\text { proximal volcanics }\end{array}$ & & \\
\hline & Hagen Mb: & Volcanic greywacke & Upper Leptite & \\
\hline \multirow[t]{5}{*}{ Grythyttan Slate Fm } & Jordan Mb: & Black slates & Slate & Slate Division \\
\hline & Hällefors Mb: & Grey slates & Group & \\
\hline & Lonnhöjden Mb: & Proximal volcaniclastics & & Upper \\
\hline & Saxhyttan Mb: & Debrites between (pebbly) slates & & Hälleflinta \\
\hline & & & & Division \\
\hline Sångshyttan Fm & & Bedded acid volcaniclastics & $\begin{array}{l}\text { Lower and Middle } \\
\text { Leptite Group }\end{array}$ & $\begin{array}{l}\text { Lower Hälleflinta } \\
\text { Division }\end{array}$ \\
\hline
\end{tabular}


interactions (Jasiński et al., 1988). Sundius (1923) put a spilitic greenstone interval between the two divisions thereby suggesting a formation boundary. Lundström (1995a) largely followed Sundius' (1923) stratigraphy of the Grythyttan field, i.e., a one-dimensional, upward sequence from older greywackes to younger slates and conglomerates, not realising the importance of lateral facies changes between the grey and black slates in the northern and central parts of the GSB and the more felsic volcaniclastic sediments in its southern part, in the Lonnhöjden area (see Fig. 2). Contrary to earlier interpretations, particularly those of Sundius (1923), our analysis does not assign the GSB to the final, post-orogenic stage of Svecofennian sedimentation. Rather, the GSB and SSB represent a distal volcaniclastic interlude between more proximal volcaniclastic deposits of the Bergslagen Group, viz. between 'Lower Leptites' and 'Upper Leptites' in the sense of Oen et al. (1982) (Tab. 1). While Högbom (1910) and Sundius (1923) and their followers advocated a tectonic model of upright isoclinal folding whereby the Grythyttan and Saxån slate belts form the cores of synclinoria (Fig. 1), we find that the strata in the GSB always dip steeply towards the west and are consequently fining (and therefore younging) towards the east along the entire length of the belt (see insets in Fig. 2). This simple pattern is complicated in the core of the $\mathrm{F}_{4}$ Sör- Älgen fold, however, due to disharmonic folding. The slate basins are part of the Bergslagen Group, as confirmed by our $\mathrm{U}-\mathrm{Pb}$ zircon data, presented below, of felsic metavolcanic samples both underlying and overlying the conglomeratic Saxhyttan member (Fig. 3). We now redefine Oen's (1987) Upper Leptite and Slate Group as being equivalent to our Grythyttan Slate Formation, the focus of this contribution, making Sundius' (1923) so-called upper and lower hälleflinta 'divisions' obsolete. Table 1 compares older lithostratigraphic divisions to our present one.

\section{Sångshyttan Formation}

The formation consists of thin- to thick-bedded felsic volcaniclastic rocks, interbedded with dolomite and

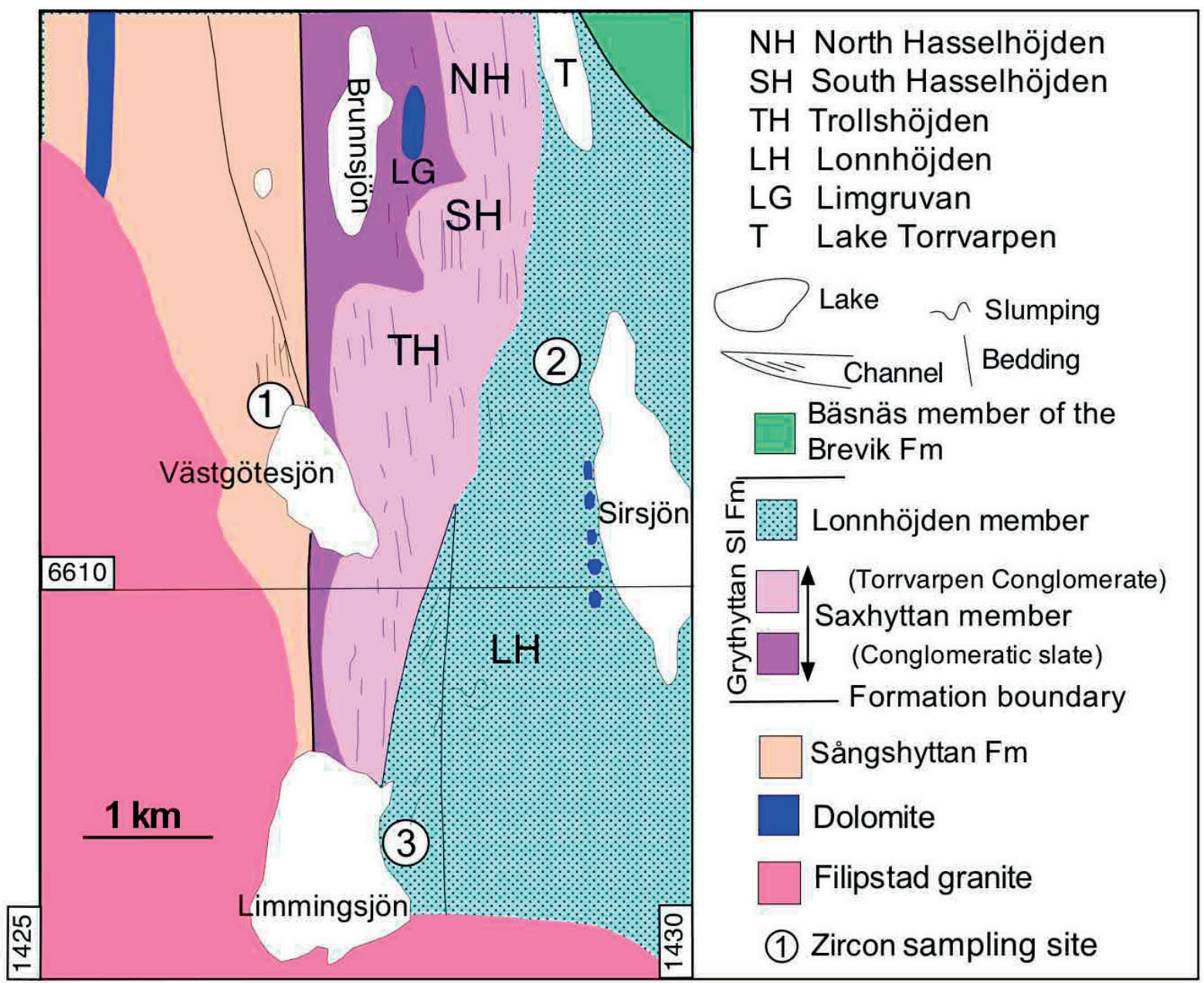

Figure 3. Lithological map of the Hasselhöjden-Lonnhöjden area of the southern GSB, with zircon dating localities 1-3. Bedding details obtained from aerial photographs in an eastward-younging sequence of volcaniclastic sediments. Note cross-sections through two km-sized, E-facing channels. 
jaspilite beds, which have been mined in the past. These well banded sedimentary ores are concentrated in the Sångs-Knuthöjden complex between the GSB and the SSB west of Hällefors (Figs. 1, 2), and resemble those of the Lake Superior banded iron formations in Canada. Here, thin limestone layers occur between thin-bedded volcaniclastic turbidites. In the Saxån-Bovik area (Fig. 2), thick featureless dolomite marble underlies the SSB, where, $1.5 \mathrm{~km}$ west of Saxhyttan, the formation contains volcanic breccias in felsic volcaniclastics dipping $60^{\circ}$ to the west, contrasting with the steep overturned dip in the Grythyttan Slate Formation. Unlike the SSB and GSB, this formation has no slates (Fig. 2). Oen (1987) classified the formation as the Lower and Middle Leptite Group (Table 1).

\section{Grythyttan Slate Formation}

Felsic volcaniclastic rocks (leptites) form the predominant lithologies of the Grythyttan Slate Formation. Although our emphasis herein is on the Grythyttan Slate Belt, we concur with Sundius' (1923) interpretation that the Grythyttan and the Saxån Slate Belts originally formed a single lithostratigraphic unit. Hellingwerf $(1984,1986,1987)$ and Hellingwerf \& Oen (1986) have shown that the SSB was affected by a synsedimentary hydrothermal system, fed by seawater, by analogy with widespread $\mathrm{Na} / \mathrm{K}$ exchange reactions and Mg-metasomatism superimposed onto many of the volcanic rocks in western Bergslagen. The obvious consequence that most or all of the Grythyttan Slate Formation was deposited in a marine environment will be discussed later on.

\section{Saxhyttan member}

Steeply west-dipping, east-facing, dark grey slates follow the lower formation boundary. The Saxhyttan member locally contains conglomeratic lenses within a volcanogenic mudstone-like matrix (Fig. 4A). The debrites northwest of Hällefors, bordering the Sangshyttan Formation to the east, commonly contain rounded quartz and jaspilite pebbles, but the matrix has chiefly angular quartz grains. No shale fragments have been found in the northern part of this member, suggesting local erosion of the Sangshyttan Formation, which has BIFs but no shale horizons in the Grythyttan Field. However, in the southern Älvestorp region (Fig. 2), the Torrvarpen conglomerates contain abundant fragments derived from locally underlying shale.

\section{Torrvarpen conglomerates}

The Älvestorp region forms the southern part of the GSB, where a nearly two kilometre-thick proximal part of an alluvial fan conformably overlies the pebbly grey slates of the Saxhyttan member to the east between Hasselhöjden and Älvestorp, and extending to the south and north over 8 km (Fig. 2; Kuipers \& Beunk, 2014). Reliable evidence for the overall younging of the sequence can be derived from an $\mathrm{E}-\mathrm{W}$ transect in the southern part of the GSB, across the Torrvarpen conglomerates and volcanic rocks on either side, between lakes Brunnsjön and Sirsjön (Figs. 1, 3). Rather than faulting (as in Wiklander \& Lundström, 1991), we interpret the western boundary as a sedimentary contact and formational boundary between underlying well-bedded volcanic deposits exhibiting $\mathrm{km}$-scale east-facing channels to the west, and stratigraphically overlying pebbly slates of the Saxhyttan member to the east (Fig. 3). About $50 \%$ of the Torrvarpen conglomerates consist of well rounded, clast-supported, conglomeratic volcaniclastic debris flows (debrites; Kuipers, 1987; Kuipers \& Beunk, 2014). Massive conglomerates form protruding lensoidalshaped topographic ridges, $5-10 \mathrm{~m}$ wide and tens of metres long, in poorly exposed volcanogenic pebbly mudstones and sandstones. The material composition of the clasts in the Torvarpen conglomerates varies considerably along the outcrop, but consists primarily of easily recognisable older volcaniclastic rocks, i.e., various kinds of metavolcaniclastic rocks and black slate (Fig. 4I-K); jaspilites are a rare component. No granite clasts have been observed. Limestone fragments are also conspicuously absent in the Torrvarpen conglomerates. Small, $\mathrm{cm}$ - to dm-sized subspherical clasts of milky quartz are commonly observed in the debris flows (Fig. $4 \mathrm{~K})$, similar to concretions of milky quartz in the slates locally underlying the Torrvarpen conglomerates and the black slates in the GSB and the SSB (Fig. 4L). The degree of rounding of the clasts varies from angular to well rounded, but well rounded, elongate pebbles predominate in the debris flows. A tectonic foliation overprints their matrix (Fig. 4M); shortening has caused strain shadows which still reveal embedding of the pebbles in the sedimentary lamination (Fig. 4K), which is a primary sedimentary structure.

\section{Shape fabric of the Torrvarpen conglomerates}

The Torrvarpen conglomerates were the subject of a study of their shape fabric (Lisle et al., 1983). Their Flinn diagram illustrates that the pebbles have an elongate blade shape and mostly exhibit plane strain geometry; slate pebbles show a more pronounced flattening. Long/ short axial ratios are up to 8 . The study by Lisle et al. was apparently conceived as a strain analysis, tacitly assuming 

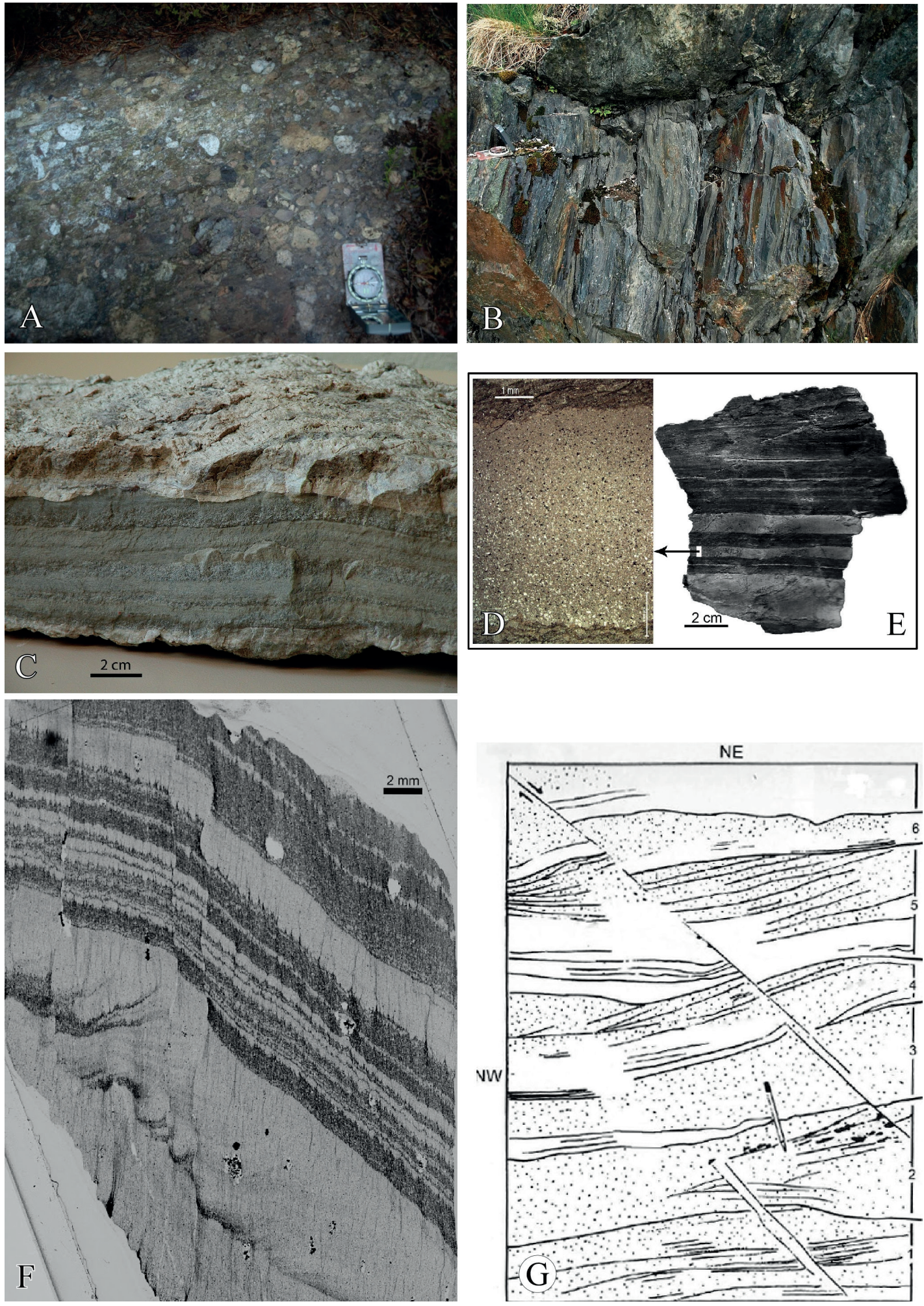

Figure 4. Field and microscopic pictures. (A) Matrix-supported conglomerate with pebbles of rounded quartz, leptite and jaspilite $1 \mathrm{~km}$ east of Sångshyttan (see Fig. 2), northernmost occurrence of the Saxhyttan Mb of the Grythyttan Slate Fm. Compass base plate is $10 \mathrm{~cm}$ long; (RT90 coordinates 142453/663453). (B) Typical thin-bedded grey slate exposure (Hällefors Mb of Grythyttan Slate Fm) near Silvergruvan bridge (Fig. 1; 142445/663816). (C) $8 \mathrm{~cm}$-thick fragment of an overbank deposit of the Hällefors $M b$ in the Lonnhöjden area (Fig. 3). Dark lower part with graded tuff layers, partly eroded by coarser-grained top of bedding. (D) PPL (parallel polarised light) thin-section of varve from the black slate member (Jordan $\mathrm{Mb}$ ) of the Grythyttan Slate Fm, on the shore of the Brevik coast of lake Sör-Älgen, showing fining upwards in the felsic siltstone band with dispersed fine carbonaceous particles from the carbonaceous layers in between (1432177/6622439). (E) The hand sample to the right of Fig. 4D shows biogenic varve couplets of clean quartz silt and carbonaceous fine tuffaceous material with high-temperature quartz pseudomorphs (Kuipers, 1987). (F) PPL micro picture of sedimentary bedding in black slate of the Jordan Mb of the GS Fm, overprinted by a steeply dipping slaty $S_{4}$ foliation. Raman spectrometry of opaque material in the black slates confirmed the presence of graphite and disordered carbonaceous material (Miljongruvan, 142955/662317). (G) Drawing after field photograph of greywacke-like, arenaceous coarse tuff, featuring six trough cross-bed sets with dip direction to the NW. Note the small black mudstone pebbles near pencil-tip. $500 \mathrm{~m}$ south of Brevik (Fig. 2; 14308/66237). 

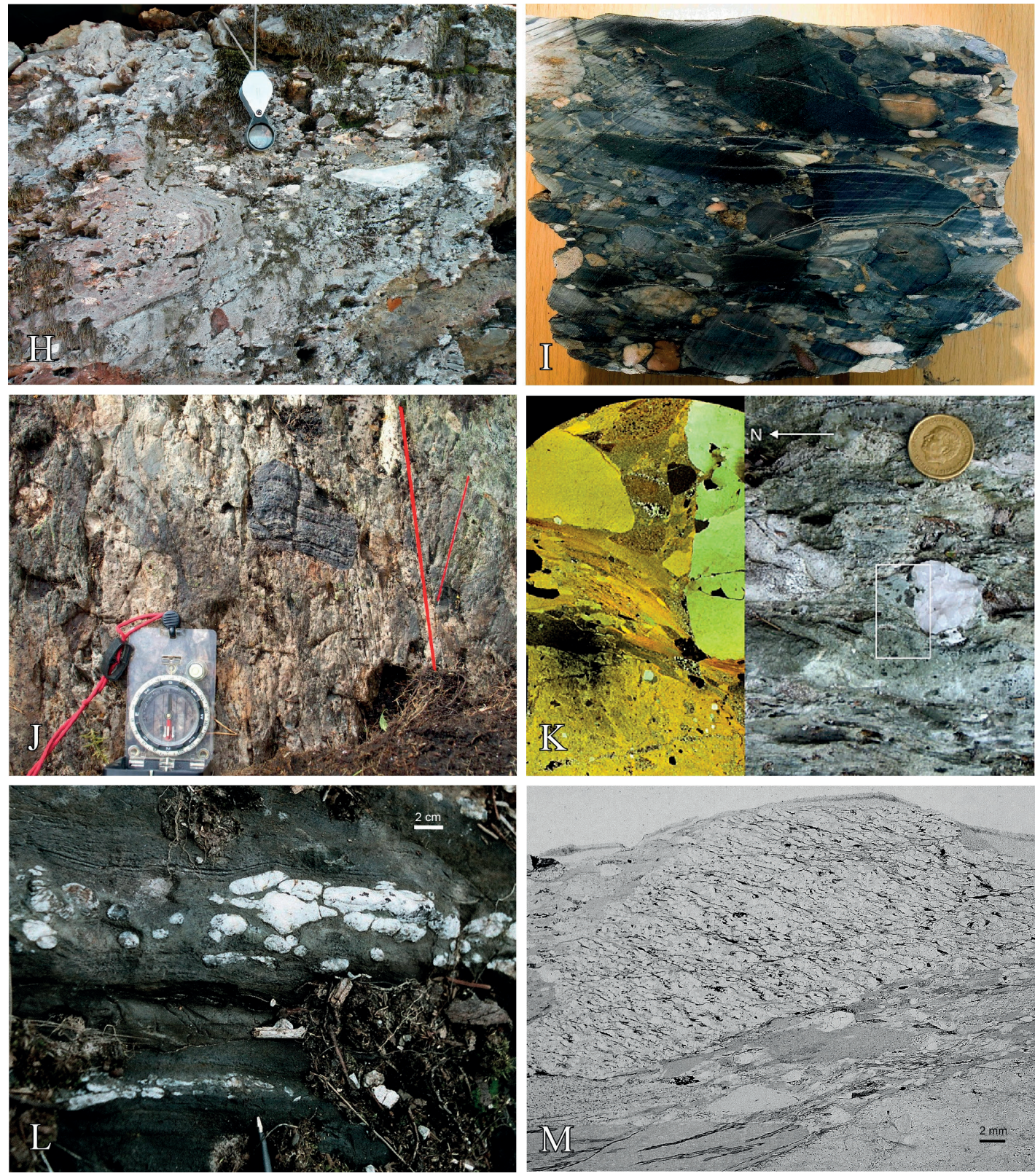

Figure 4. (Continued) (H) Polymict sedimentary breccias lining fault zone along the eastern margin of the GSB. A tightly folded slab of banded, porous metavolcanic leptite (lower left side) indicates soft-sediment deformation (143095/661949). (I) Saw cut (25 x $30 \mathrm{~cm})$ of a conglomerate of the Saxhyttan Mb, perpendicular to the bedding and foliation at South Hasselhöjden (Fig. 3), showing poorly sorted, clast-supported conglomerate, with angular black slate and rounded leptite fragments. (J) A laminated dark shale fragment at right angles to the bedding plane facing east (to the left). The thick red line (right side) indicates bedding. The thinner line shows planar cross-bedding in a thin-bedded conglomeratic unit of the Torrvarpen conglomerate unit. Note the virtual absence of internal deformation of the pebble, arguing against its ductile shortening in the E-W direction (1427808/6613430). (K) Torrvarpen conglomerate: strain shadows lateral to quartz clast. Left: XPL (cross polarised light) thin-section of rectangular area shown to the right. Fine-grained laminations abut against the clast, filling wedge-shaped domains between converging laminae. Foliation bending indicates synsedimentary shearing in debris flows, and some post-depositional pure shear. Diameter of coin is $2 \mathrm{~cm}$ (142771/661247). (L) Very thin-bedded dark blue-grey slates with quartz concretions; picture facing west near top of the SSB (1416177/6631647). (M) PPL micro picture of Torrvarpen conglomerate of the Saxhyttan Mb: metagreywacke pebble and matrix. Bedding is parallel to the lower contact between pebble and matrix, and to matrix foliation. The latter is identified as $S_{4}($ Beunk \& Kuipers, 2012). The pebble has an internal, older biotite foliation, dipping to the right in the picture, crenulated by a retrogressive $S_{4}($ biotite + chlorite). 

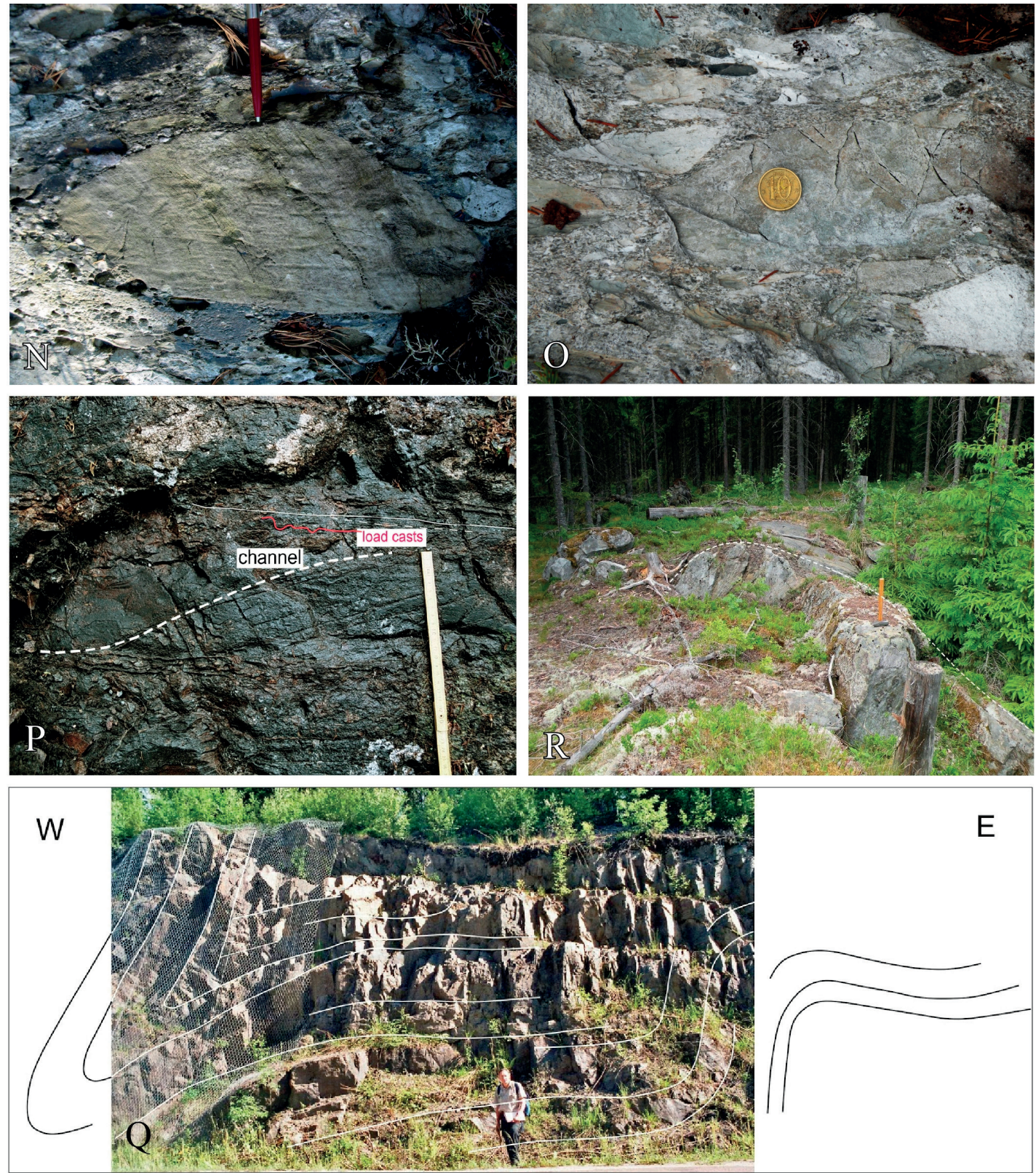

Figure 4. (Continued) (N) Prime example of metatuff fragment (centre) in Torrvarpen conglomerate; air fall tuff boulder with undisturbed internal bedding at a high angle to the approximately $N-S$ striking bedding of the Torrvarpen conglomerates, horizontal in picture, similar to Fig. $4 J(141240 / 655695)$. (O) Brittle, X-shaped conjugate fractures in leptite clast (under and to the right of coin) in Torrvarpen conglomerate. Top view with top to the east. Acute angle between fractures encloses horizontal principal compressive stress vector in the $E-W$ direction. Diameter of coin is $2 \mathrm{~cm}$ (1427403/6612500). (P) Channelling in coarse-grained cross-bedded turbidites of the Sångshyttan Fm underlying the SSB $2.6 \mathrm{~km}$ southeast of Saxån, picture facing west. Stick is $37 \mathrm{~cm}$ long (1428678/6633700). (Q) Partly broken east-vergent $F_{2}$ box fold in thick-bedded leptites. Horizontal fold axes trend close to north. Bedding planes indicated for clarity. Road-cut in northern part of SSB. Vertical structures are an artefact of excavation. Second author $(1.80 \mathrm{~m})$ for scale (1414782/6639134). (R) Upright $F_{2}$ fold in leptites directly west of the SSB, close to the northeastern arm of lake Yngen. Hammer stands on N002E-trending fold hinge, dashed line follows bedding (1416228/6630246).

that the fabric resulted from ductile deformation. We reject their implicit conclusion for reasons explained here, and posit instead that the clast shapes and their fabric resulted from erosional processes alone. Long $(\mathrm{x})$ and intermediate (y) axes of the gravels are generally parallel to the internal bedding planes of metavolcanic clasts, which tend be oriented with their $x-y$ axes subparallel to bedding in the conglomerates. Internal deformation of the pebbles is absent or minimal at most, as shown in places by the (nearly) undeformed internal laminations at a high angle to external bedding and foliation (e.g., Figs. 4J, N). The only phenomena of tectonic shortening of pebbles across bedding are brittle, not ductile (e.g., Fig. 4O). At the local peak metamorphic temperature of c. $300^{\circ} \mathrm{C}$, 

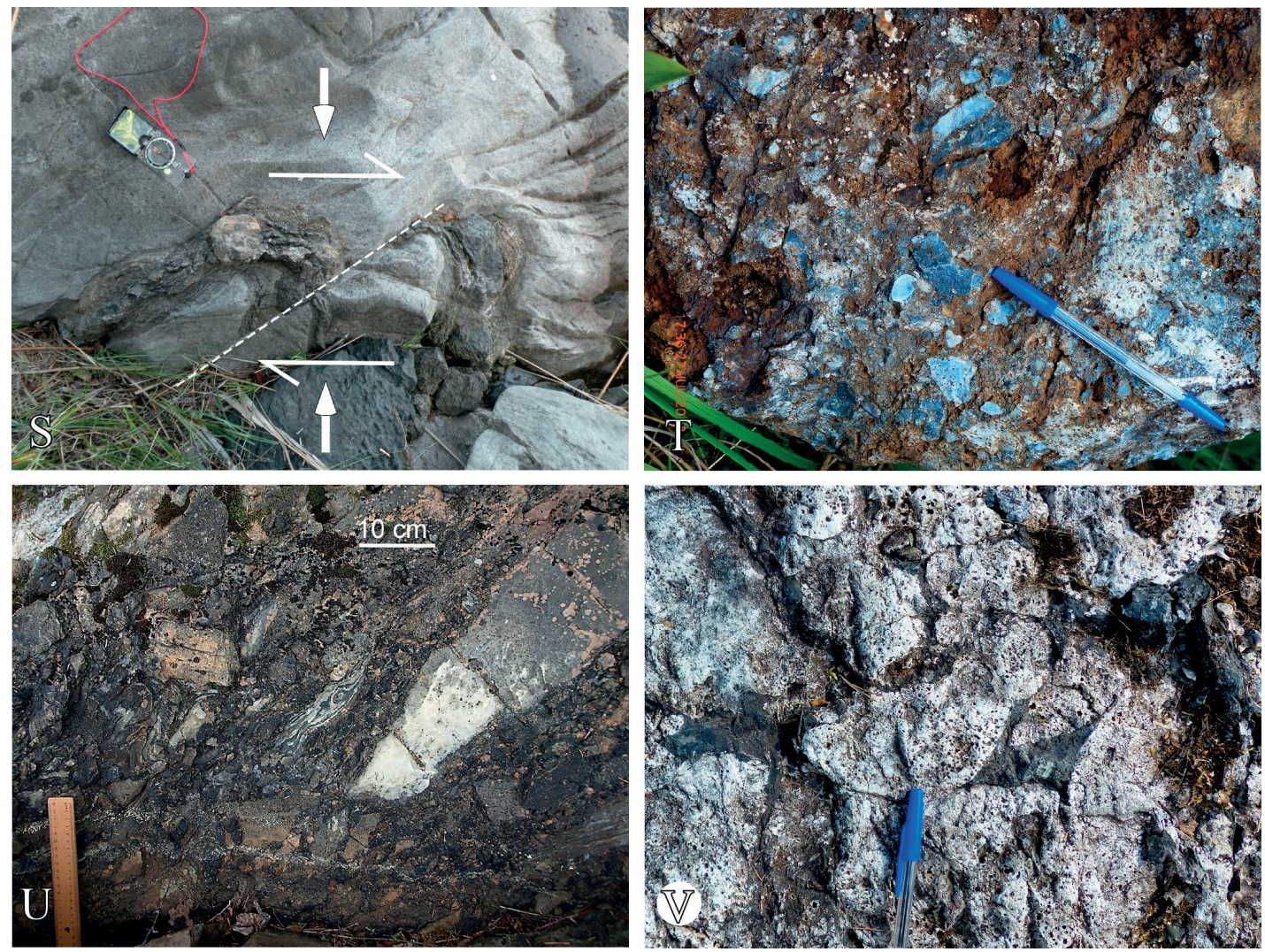

Figure 4. (Continued) (S) Top view of minor, Z-shaped $F_{4}$ shear fold with near-vertical b-axis plunging at $80^{\circ}$, in thinly laminated metavolcanic bed embedded in a thick marble of the Bergslagen Group along the northwestern margin of the SSB. Compass points N. Halfarrows show direction of dextral shear; transverse (transpressional) shortening (full arrows) broke the fold along stippled line. The minor fold witnesses preferential, map-scale partitioning of $D_{4}$ shearing into marbles and slates. Compass base plate is $10 \mathrm{~cm}$ long (1416468/6630146). (T) Monomict fault breccia in felsic metavolcanic rocks of the Bergslagen Group, eastern GSB margin. Hurtigtorpet, $1 \mathrm{~km}$ east of Hällefors (142923/663039). (U) Monomict limestone breccia on the eastern shore of lake South Torrvarpen $3 \mathrm{~km}$ north of Älvestorp. This represents the broken top part of the Bäsnäs Mb (142898/661603). (V) White-weathering felsic, porphyritic metavolcanic rock (leptite) along the eastern faulted margin of the GSB, broken and net-veined by black pseudotachylite injections, $4.5 \mathrm{~km}$ north of Hällefors (142767/663475).

derived from chlorite compositions in the conglomerates (Beunk, unpublished results), intense ductile deformation is unlikely; at $300^{\circ} \mathrm{C}$ feldspar still behaves in a brittle manner, while quartz just reaches the lower temperature limit for intracrystalline deformation (e.g., Passchier \& Trouw, 2005). Had the discoidal shape of the silicic clasts resulted from volume loss by pressure solution deformation, the formation would have been massively veined by quartz, which is absent at the expected scale. Yet, the conglomerates exhibit a pronounced shape fabric, which we illustrate, in addition to the study of Lisle et al. (1983), by measurements of the orientations of long axes of pebbles from two locations. They show identical results, viz. sharply defined maxima parallel to bedding, plunging steeply to the NNW (Fig. 5). The fabric is deceptively similar to a tectonic one and might be taken as a b-lineation belonging to the $\mathrm{D}_{4}$ deformation (i.e., vertical fold axes). Note, however, the absence of folding of the southern part of the GSB at the scale of the local map (Figs. 1,2 \& 3). Also note the occasional pebble with a horizontal long axis (Fig. 5B). We conclude that the shape fabric of the Torrvarpen conglomerates has a sedimentary origin, which is characteristically observed in alluvialfan deposits like stream, flood and debris flows; the parallel alignment of clasts in the direction of transport is probably related to high rates of laminar shear straining of individual surges (Enos, 1977; Major, 1997, 1998). Hence, the individual conglomeratic ridges form cross sections through much longer, steeply plunging tongues, which, when rotated back to the horizontal along the strike direction of bedding (Fig. 5), strike SW-NE, in the direction of transport of the debris flows. The erosional process responsible for the discoidal clast shapes and the unaltered nature of the black shale fragments (Fig. 4I) could have been glaciogenic and inherited from nearby tills, which are not exposed however. Indications for subarctic conditions are deduced from cryoturbation in the Bergslagen Group at some distance but are of the same age (Kuipers et al., 2013; in prep). 


\section{Lonnhöjden member}

West of Älvestorp in the Lonnhöjden area (Fig. 3), felsic pyroclastic flows follow conformably the conglomeratic debris flows of the Saxhyttan member in large channels, as can be seen from aerial photographs. Sundius (1923) described the sequence of bedded felsic volcanic rocks as sedimentary hälleflinta. The Lonnhöjden area, with diverse proximal, medial and distal felsic volcaniclastic facies, e.g., thin turbidites, thick ignimbrites and airfall tephra (Fig. 4C), is featuring high effusive activity from nearby subaerial volcanoes. The more distal facies are represented by the grey slates around Hällefors and the black slates of the Jordan member.

\section{Hällefors member}

The grey slates overlying the Saxhyttan member are defined as turbidites containing reworked fine metavolcaniclastic rocks with sericite prevailing in the matrix (Fig. 4B). Kuipers (1987) described these rocks as a rhythmically bedded sequence of tuffites resembling low concentration sediment gravity flows. North of Grythyttan no clear contact with the overlying Jordan member has been established, possibly as a result of a gradual basinward transition from a first-stage erosional event with debris flows, followed by $\mathrm{T}_{\mathrm{a}, \mathrm{b}}$ turbidites (Bouma, 1962), evolving into medial thin-bedded $\mathrm{T}_{c, \mathrm{~d}}$ turbidites and finally into $\mathrm{T}_{\mathrm{e}, \mathrm{f}}$ type basinal black shale of the overlying Jordan member. Like in the underlying rocks of the Grythyttan basin, only a single foliation characterises the metamorphic fabric of the Hällefors member in the Lonnhöjden area. In agreement with published geological maps (Wiklander \& Lundström, 1991; Lundström, 1995b), this member is terminated in the north and south of Fig. 2 by a major fault, further described in the section on the structure of the GF.

\section{Jordan member (Grythyttan black slate)}

Jordan is a locality $2 \mathrm{~km}$ northeast of Grythyttan, with good exposures of the black slates, exhibiting all colour grades from grey to black, depending on the carbon content of the rock. The Grythyttan slate quarry $0.6 \mathrm{~km}$ south of the town contains large quantities of carbonaceous slate, which commonly display a pronounced rhythmic layering. Couplets of thin silty and very fine carbonaceous material resemble varves (e.g., Fig. 4D, E). The darker organic background sedimentation could be the result of periodic eutrophic conditions with abundant algal blooms mixed with a continuous supply of felsic ash, settling in a stagnant water column and generating thin, graded, silt laminae covered by a mix of dead algae and very fine, hightemperature quartz particles from air fall ash (Oen et al., 1986; Kuipers, 1987). Thickness of the banding can vary from $\mathrm{mm}$ to $\mathrm{cm}$. Pseudo-conglomeratic quartz concretions have been observed in the black slates by Sundius (1923) and others. The Jordan member exhibits
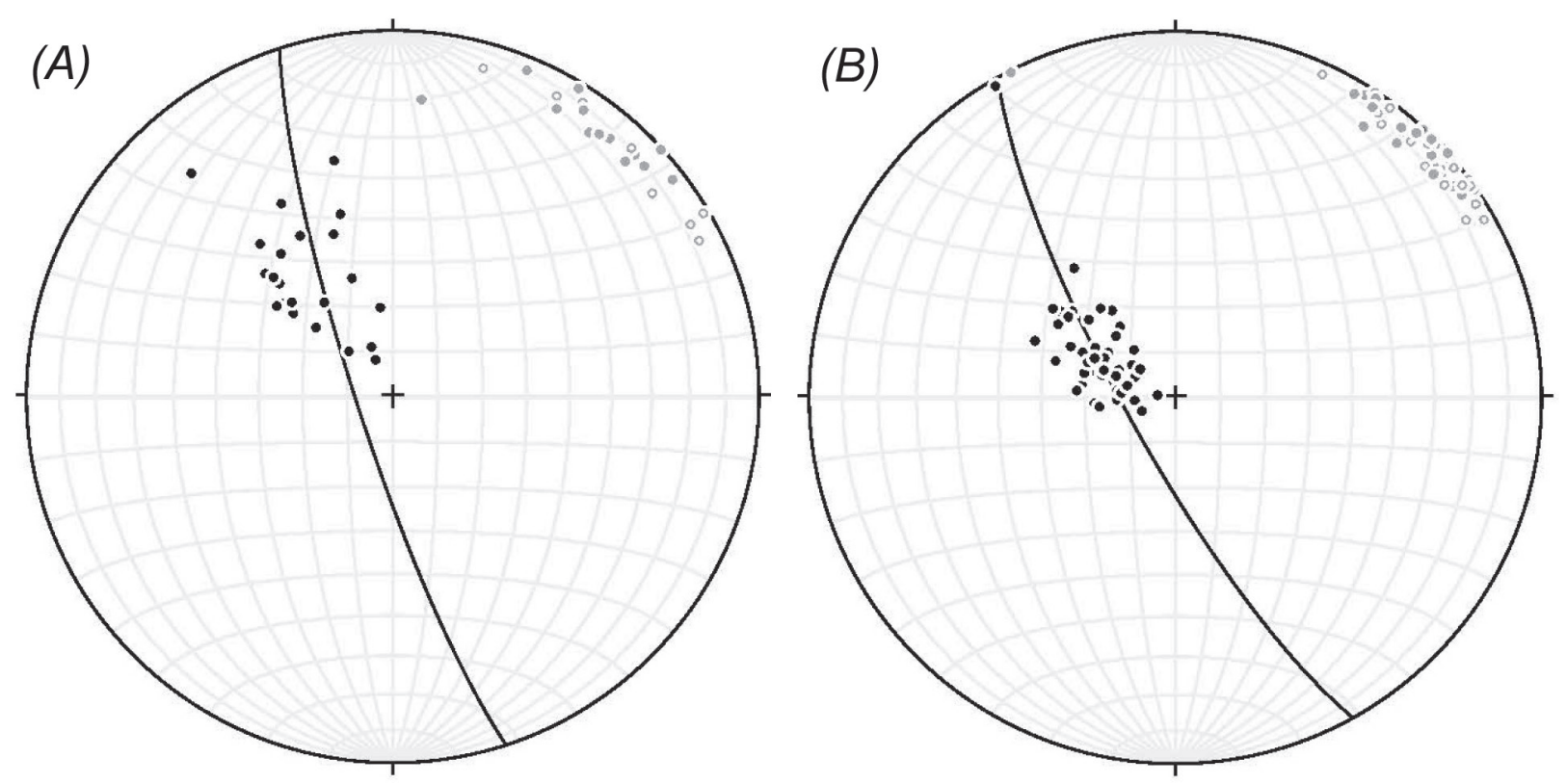

Figure 5. Stereographic projections of directions of steeply NNW-plunging long axes of pebbles of the Torrvarpen conglomerates from outcrops 13.51 ((A), 142775/661230) and 13.73 ((B), 142759/661255) and the steeply overturned bedding plane (great circle). Symbols in grey are plunges rotated back to the horizontal along strike of bedding; closed symbols plot on lower hemisphere, open symbols on upper hemisphere. Note the single pebble with horizontal long axis in (B). See text for discussion. 
a single metamorphic foliation (Fig. 4F) and steeply plunging bedding/cleavage intersection lineations (Fig. 1), witnessing a second-generation $\left(\mathrm{F}_{4}\right)$ folding. This observation led Beunk \& Kuipers (2012) to suggest a post $\mathrm{D}_{2}$ age of sedimentation.

\section{Brevik Formation}

This formation has an erosional unconformity with the underlying Grythyttan Slate Formation, from which it has partially eroded the Grythyttan black slates before they became lithified. The lower part consists of very coarse, greywacke-like, volcaniclastic rocks followed by proximal felsic volcanic rocks, i.e., ignimbrites.

\section{Hagen member}

Coarse felsic volcaniclastics containing rip-up shale clasts were mapped by Sundius (1923) and described by Lundström (1995a) south and east of Grythyttan in the Hagen and Brevik areas. Locally they contain peperites (Kuipers, 1987). The flow direction inferred from trough cross bedding displayed in Fig. 4G suggests a sediment source to the south. Sundius (1923) places the Grythyttan black slates of the Jordan member stratigraphically above the greywackes of the Hagen member, in contrast to our interpretation of the Grythyttan Slate Formation as an eastward younging sequence of locally unconformable coarse volcaniclastic sediments. Therefore, the volcanogenic greywackes in the Brevik area overlie the black slates and alternate with quartz porphyry lava and ignimbrite flows displaying glass shards to the north and east (Kuipers, 1987). It seems that the distal black slates of the Jordan member were followed by proximal and medial volcaniclastics related to Plinian eruptions. The fining up part of the Grythyttan Slate Formation stops with the Hagen member, which has a coarse-grained greywacke-like texture.

\section{Bäsnäs member}

Conformably overlying the volcanic greywackes of the Hagen member is a sequence of welded pyroclastic flows, i.e., ignimbrites with glass shard textures (Kuipers, 1987). The pyroclastic flows resemble rhyolitic lava with autoclastic breccias, which may be caused by brecciation of the top of subaqueous flows (Schmincke \& Swanson, 1967). Southeast of Bäsnäs, near the Båtberget locality, massive coarse tuffs to monomict agglomerates containing abundant angular rhyolitic fragments up to $10 \mathrm{~cm}$ in size resemble pyroclastic debris flows, but could also be interpreted as fault-scarp breccias (Van der Velden et al., 1982). Slump structures occur at several localities (Fig. 4H). The upper finer-grained part is obscured by a mafic sill.

\section{Volcaniclastic facies relationships}

Volcaniclastic facies, like sedimentary facies, indicate the aspect or character of the rocks in a succession of beds (Fig. 6; Pettijohn, 1975). Facies can be displayed by maps like Figs. $2 \& 3$, because they are an expression of areal variation in aspect of rocks in a time-stratigraphic unit. Therefore, geological maps based on facies associations like ours show broad regional trends in lithology, whereby a chronostratigraphic unit which consists of mainly slates in one area may be correlated with thick- and or thin-bedded leptites in another. Our interpretation of the spatial facies distribution in the Grythyttan basin is given in Table 1 and Figs. 2, 3 \& 6 .

\section{Structure of the Grythyttan Field}

In general, the structure of the GF reflects the interference of folds of two generations, equivalent to the $\mathrm{F}_{2}$ and $\mathrm{F}_{4}$ phases defined for Bergslagen as a whole by Beunk \& Kuipers (2012), and both varying in scale from centimetres to kilometres. Folding is facilitated by the well bedded nature of the supracrustal rocks of the Bergslagen Group. $\mathrm{F}_{2}$ folds, with sub-horizontal axes, are upright, overturned and east verging; they originate from E-W shortening of this part of Bergslagen (in presentday coordinates). An anticlinorial structure between the GSB and the SSB was already identified by Högbom (1910, see inset to our Fig. 1) and Sundius (1923) and forms the main expression of $\mathrm{F}_{2}$ folding in the GF (Figs. 1 \& 2). Right-lateral $\mathrm{D}_{4}$ shearing gave rise to $\mathrm{Z}$-shaped $\mathrm{F}_{4}$ folds in map view, with subvertical axes, best exemplified by the km-scale Sör-Älgen fold in the GSB (Fig. 1). Additional map-scale $\mathrm{F}_{4}$ folds deform a slate-sandstone syncline directly east of lake Sirsjön (Fig. 1, and on Sundius' map (1923)), and form a Z-shaped mafic body directly north of this structure (Fig. 1).

On the eastern side of the map of Fig. 1, two granitegranophyre cored volcano-plutonic complexes, Hjulsjö and Sundsjö, have to a large extent retained their original two-dimensional subcircular shape with radially outward-dipping volcanic bedding. Probably stiffened by their granite cores, they acted as competent markers amidst their well bedded, more distal and less competent metavolcanic surroundings and have largely escaped lateral $\mathrm{D}_{2}$ shortening. Their undeformed map appearance 


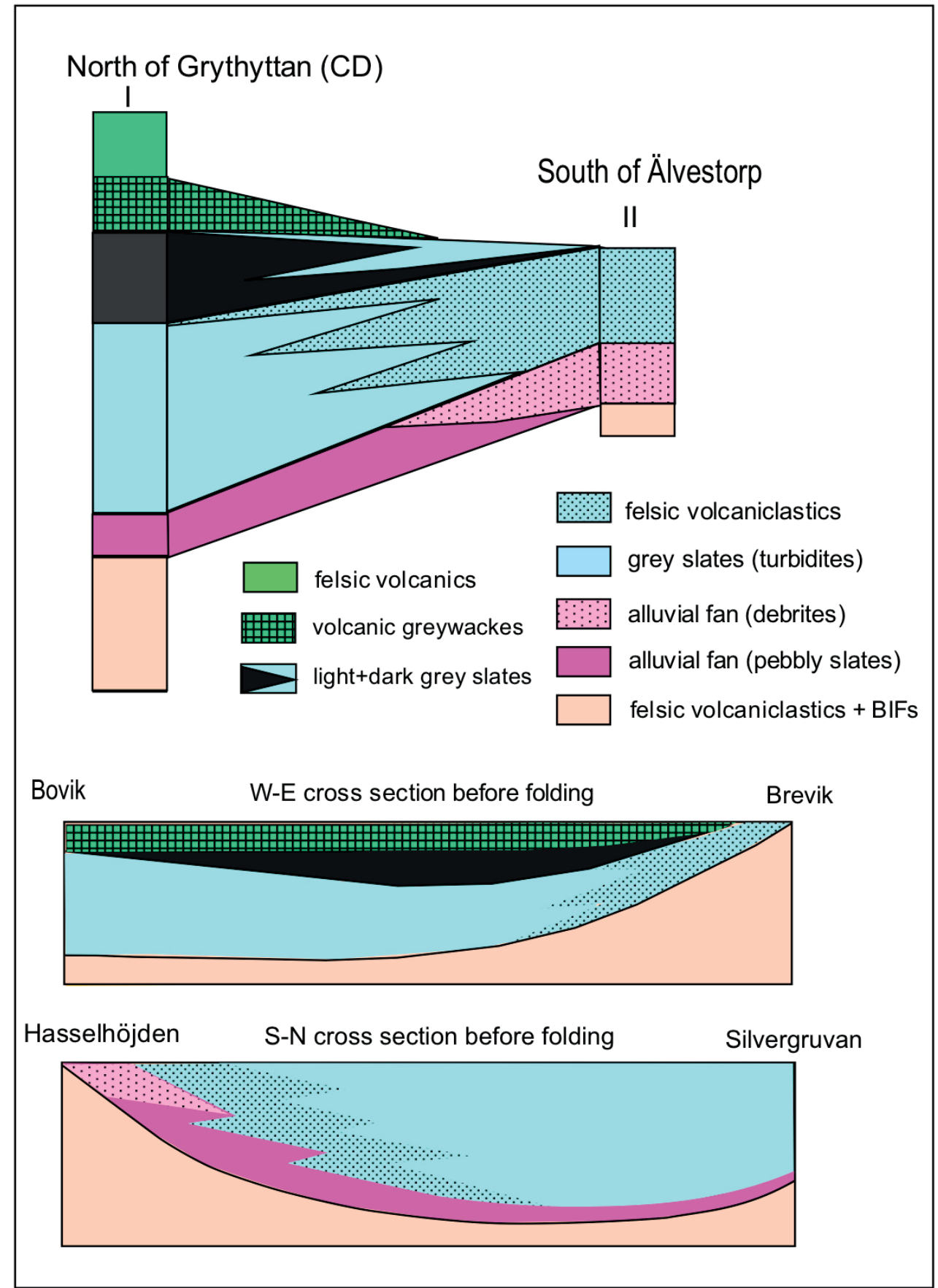

Figure 6. Interpretation of the volcaniclastic facies relations in the Grythyttan basin, which produce a stratigraphy whereby the grey slates (distal facies) are time equivalent with the (proximal) felsic volcaniclastics (leptites). Colours in this chart indicate lithologies, while those in Figs. 2 \& 3 identify lithostratigraphic members.

led Beunk \& Valbracht (1991) to suggest the lack of regional penetrative shortening for western Bergslagen as a whole, which is obviously incorrect. These former volcanic centres seem to have determined the location of the disharmonic hinge of the $\mathrm{F}_{4}$ Sör-Älgen fold, which bulges eastward into the space between the two palaeo-volcanoes (Fig. 1). Because of ubiquitous parasitic folding, the general lack of marker horizons and the dearth of outcrops it is nowadays difficult to describe the overall structure of the GF in great detail. Earlier on, under much lower forest cover, Sundius (1923) produced probably the best existing map of the GSB and its surroundings. However, the direction of stratigraphic younging in the GSB is a key element in the structural interpretation of the Grythyttan Field. The interpretation of a synclinorial structure after Högbom (1910) and Sundius (1923) requires inward younging from both sides of the structure, but it is not based on way-up observations. The most recent map from the Swedish Geological Survey (Wiklander \& Lundström, 1991) similarly depicts an inward (i.e., westward) younging direction in the slates on the eastern side of the thickened 
hinge of the $\mathrm{F}_{4}$ Sör-Älgen fold, but in our experience younging directions in this part of the structure switch repeatedly from west-younging to east-younging as a consequence of parasitic $\mathrm{F}_{4}$ folding of the rocks. Hence, comprehensive mapping of the areal variation in younging directions is also difficult. Rather, we have to rely on basin-scale sedimentary facies association variations of the volcaniclastic sediments in time and space (Fig. 6) as clues to the overall tectonic structure, here summarised in Fig. 2. Details supporting our present interpretation are given in the remainder of this section.

Above and within the Torrvarpen conglomerates along the southern EF transect (Fig. 2), several outcrop-scale structures indicate eastward younging of the strata (e.g., Fig. 4J). Cleavage and bedding planes are subparallel, steeply WSW dipping, indicating their position in a limb of a (large-scale) isoclinal fold. The map contact between the slates of the Saxhyttan member and the Torrvarpen conglomerate lens is distinctly non-planar (Fig. 3) and suggests loading and channelling by the alluvial-fan conglomerate lens into underlying pebbly mudstones. To the east, the Lonnhöjden felsic volcanic rocks have filled large channels, sometimes with eroded conglomerates, also suggesting eastward younging. Only locally, from aerial photography as well as outcrop observation, have we observed folding of thin-bedded volcaniclastics, which we interpret as slump folds (Fig. 3). Overall, the section seems to be consistently east-younging, consistent with our present interpretation that it occupies the limb of a large-scale antiform. Hence, the entire GSB seems to occupy an east-facing near-vertical fold limb, slightly overturned in the southern Hasselhöjden area and strongly affected by $\mathrm{D}_{4}$ shearing in its widest part around Grythyttan.

In the corridor of volcanic rocks of the BG between the Grythyttan and Saxån slate belts (Fig. 1), Damman (1989) mapped regional sub horizontal bedding planes in metavolcanic sedimentary rocks of the BG near Gåsborn. South of Saxån, bedding planes in the Sångshyttan Formation dip steeply west and show westward younging directions, as indicated by channel cross bedding (Fig. $4 \mathrm{P})$, before reaching the SSB proper. In the black slates near Dammhyttan (3.5 km northwest of Saxån), there are quartz concretions similar to those described by Sundius (1923) in the Grythyttan area (Fig. 4L). The northern part of the SSB contains abundant thin-bedded, competent volcaniclastic sandstone beds in places interlayered with very thin shale beds. Herein, just east of the northern tip of lake Långban, a large east-verging $\mathrm{F}_{2}$ box fold is exposed (Fig. 4Q), illustrating that the slate belts were indeed affected by this early folding, together with their neighbouring BG metavolcanic rocks (e.g., Fig. $4 \mathrm{R}$ ), and that subsequent vertical $\mathrm{F}_{4}$ shear folding mainly partitioned into different, slaty and dolomitic parts of the belts (e.g., Fig. 4S). The observations support the existence of a km-scale anticlinorial $\mathrm{B}_{2}$ axis along the corridor of BG volcanic rocks between the Grythyttan and Saxån slate belts. In all, the SSB and GSB are here interpreted as the steeply dipping western and eastern limbs of a $10 \mathrm{~km}$-scale, subhorizontal, east-vergent $F_{2}$ fold, with a normal western limb (SSB) and a slightly overturned eastern limb (GSB). The anticlinorial axial domain is occupied by the Sångshyttan Formation (Fig. 2). Both slate belts represent sections through the same depositional (slate) basin, where the Grythyttan belt represents a more central part of the original basin than the peripheral Saxån belt. The breccia zone along the eastern margin of the GSB contains in situ brecciated felsic and mafic metavolcanic rocks of the Bergslagen Group (Fig. 4T, and Fig. 5D-F in Beunk \& Kuipers, 2012) as well as sedimentary breccias derived from volcanic slopes or fault scarps as avalanche breccias (Fig. $4 \mathrm{H}$, $\mathrm{U})$. The breccia zone pre-dates $\mathrm{D}_{4}$ deformation, as the zone as a whole has been folded along the $\mathrm{F}_{4}$ Sör- Älgen fold, while a brecciated mafic body along this fault zone shows indicators of dextral $\mathrm{D}_{4}$ shear (Fig. $5 \mathrm{E}$ in Beunk \& Kuipers, 2012). The zone is studded with such mafic rocks. Its association with sedimentary breccias strongly suggests synsedimentary activity of the fault, also predating $\mathrm{F}_{2}$ folding. For those reasons we interpret the zone as a $D_{1}$ structure, i.e., normal, probably listric faulting accommodating rifting. However, the present overall structure, with largely undeformed volcanic complexes to the east (Fig. 1), and the east-vergent fold structure of the SSB-GSB to the west, suggests that the extensional $\mathrm{D}_{1}$ fault was rejuvenated by $\mathrm{D}_{2}$ shortening, and that the anticlinorial structure of the SSB-GSB forms (the frontal part of) an imbricate $\mathrm{D}_{2}$ thrust belt (Fig. 2, profile $\mathrm{AB}$ ). An occurrence of pseudotachylite veining (Fig. $4 \mathrm{~V}$ ) along the western margin of the fault zone is consistent with this interpretation, exposing relatively deeper levels in the hanging wall of the $\mathrm{D}_{2}$ fault. The disappearance of the Jordan and Bäsnäs members in the northern part of the GSB may be a consequence of oblique intersection of the lithostratigraphy by the $\mathrm{D}_{1} / \mathrm{D}_{2}$ fault.

\section{Geochronology}

An indication of the relative depositional age of the Torrvarpen conglomerates is given by the occurrence of previously foliated clasts of metavolcanic rocks of the BG (Fig. 4M). The slates and the matrix of the conglomerates exhibit only a single foliation (Fig. 4F, M), apparently related to vertical $\mathrm{F}_{4}$ folding. $\mathrm{S}_{2}$ in micaceous rocks in the higher-grade parts of West Bergslagen was crenulated by $\mathrm{S}_{4}$. Hence, Beunk \& Kuipers (2012) proposed that the Grythyttan slates and Torrvarpen conglomerates were deposited at around $1.85 \mathrm{Ga}$, after the regional $\mathrm{D}_{2}$ deformation which closed the volcanic back-arc basin of the Bergslagen Group. Our present geochronology aims to verify the inferred age of deposition of the GSB, and its role in the tectonics of Bergslagen. We separated zircons from felsic metavolcanic rocks from three sites shown 
in Fig. 3, bracketing the Torrvarpen conglomerates, using magnetic and centrifugal assisted heavy-liquid separations. All samples delivered euhedral, prismatic bipyramidal zircons with obvious oscillatory magmatic zonation.

The sample from site 1 (Bk1519) is a metarhyolite of the Sångshyttan Formation (Figs. 2 \& 3), immediately underlying the basal unconformity at the southern end of the GSB to the west. It has a poorly foliated, fine-grained $(\sim 100 \mu \mathrm{m})$, quartz + sericite matrix with small $(\sim 1 \mathrm{~mm})$ phenocrysts of Kspar and pseudomorphs after embayed a-quartz. Sparse patches of opaque phases (ilmenite?) are intergrown with titanite and epidote. In addition, abundant porphyroblasts of a colourless clinoamphibole of the cummingtonite-grunerite series overgrow the matrix. The Sångshyttan Formation is marine, as witnessed by the occurrence of BIFs, marble horizons and, in the case of the metarhyolitic zircon sample, by the metamorphic Mg-amphiboles, which reflect widespread submarine, synsedimentary, hydrothermal Mg-alteration of the metavolcanic supracrustal rocks of Bergslagen (e.g., Frietsch, 1975; Baker \& De Groot, 1983). Two size fractions of zircons were isolated, 90-120 $\mu \mathrm{m}$ and 120$180 \mu \mathrm{m}$.

Samples from sites 2 and 3 are felsic volcaniclastic rocks of the Hällefors member covering the Torrvarpen
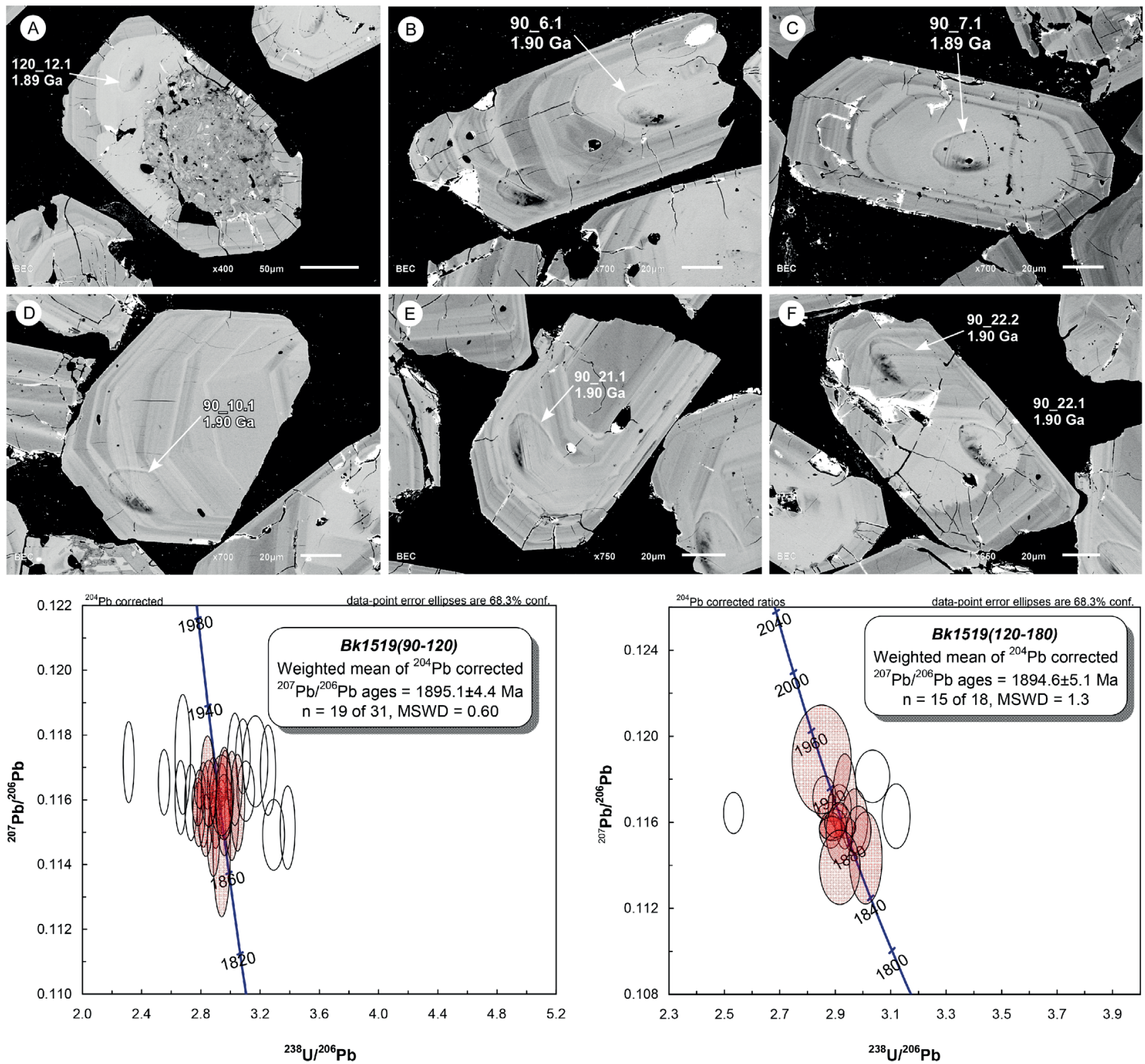

Figure 7. Selected EBS images (A)-(F) of SHRIMP-analysed zircons, and Tera-Wasserburg isochron plots from cummingtonite-rich quartzKspar phyric metarhyolite Bk1519 of site 1 (Fig. 3), in the Sångshyttan Fm of the Bergslagen Group, directly underlying the Grythyttan Slate Fm (Figs. 2 \& 3). Scale bar is $50 \mu \mathrm{m}$ in (A), and $20 \mu \mathrm{m}$ in (B)-(F). Arrows with spot identifiers (see Table 2) point to pits sputtered by the ion beam. An older, porous and metamict core is visible in (A), from the 120-180 $\mu \mathrm{m}$ size fraction. 
conglomerate to the east. The outcrop of site 2 exposes $\mathrm{dm}$ - to $\mathrm{m}$-thick beds of massive to variably foliated, fine-grained, aphyric to quartz-Kspar phyric $(\leq 2 \mathrm{~mm})$ metarhyolites, exhibiting a single foliation in thinsection. Fine-grained $(\sim 100 \mu \mathrm{m})$ quartz matrices of the foliated specimens are rich in sericite, or, where somewhat coarser grained, in weakly pleochroic phlogopitic mica. Matrices contain subordinate carbonate minerals. Zircons from size fraction $<60 \mu \mathrm{m}$ of samples Bk1306 (massive) and 1308 (more foliated) were combined. Sample Bk1307 (massive) allowed separation of a $60-90 \mu \mathrm{m}$ zircon fraction. All zircons from this site are prismatic bipyramidal, semi-transparent and slightly pinkish coloured. Sample Bk1313 from site 3 is a very fine-grained $(<50 \mu \mathrm{m})$, aphyric, sericitic leptite, with conspicuous cataclastic veins filled with epidote (older) or quartz (younger). The sample delivered $<60$ $\mu \mathrm{m}$, short prismatic, bipyramidal, transparent, slightly reddish to colourless zircons. In situ U-Pb zircon ages were determined using a Sensitive High Resolution Ion Microprobe (SHRIMP IIe) housed at KBSI, using the 1099 Ma old FC1 zircon standard (Paces \& Miller, 1993). Analytical techniques follow the routine procedures described in Cho et al. (2013). Our U-Pb isotopic results are given in Table 2. Figs. 7-9 show some representative electron backscatter (EBS) images of the three sites. With few exceptions (Table 2), measured $\mathrm{Th} / \mathrm{U}$ ratios are well above 0.2 , consistent with a magmatic origin for
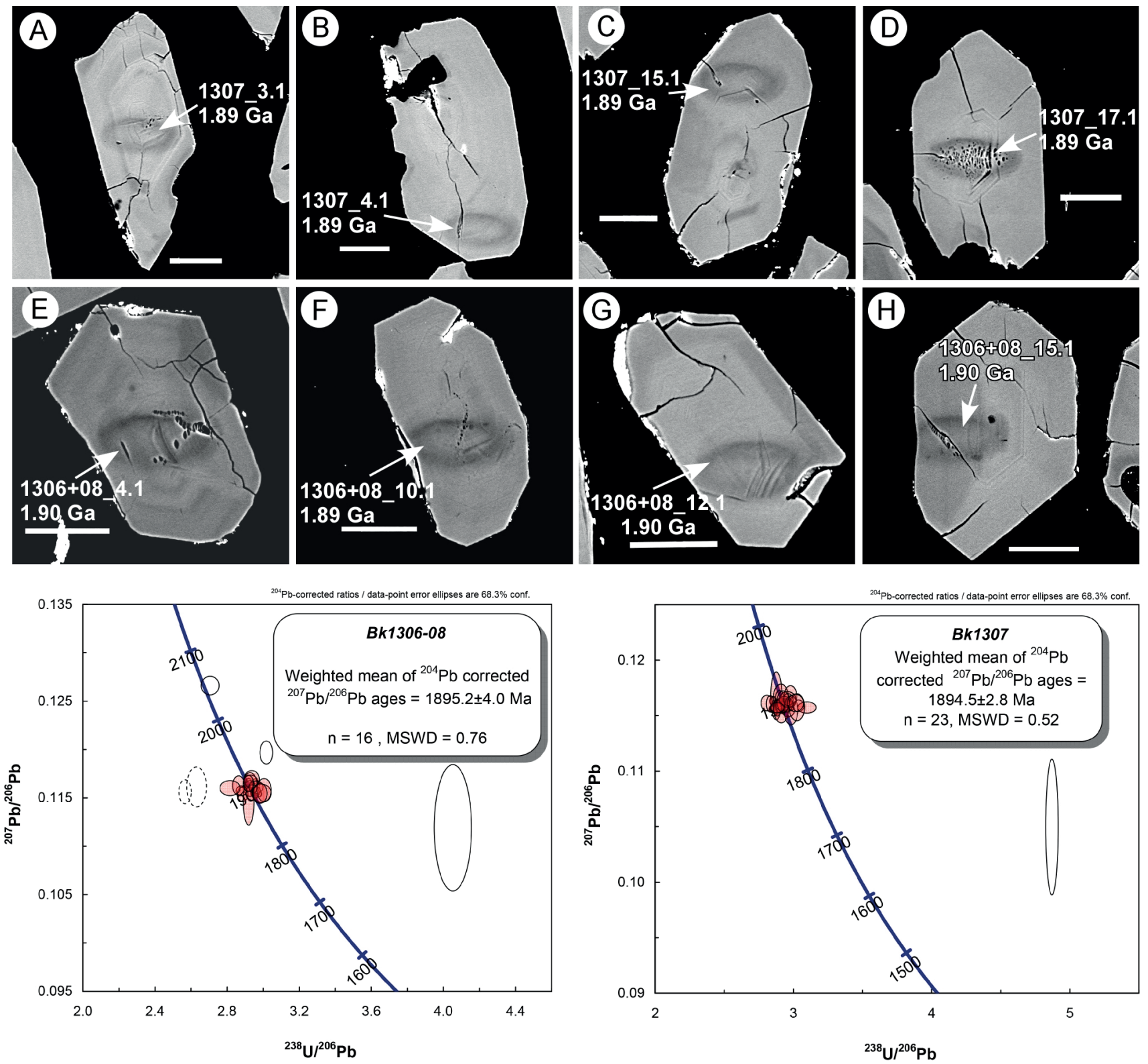

Figure 8. Selected EBS images (A)-(H) of SHRIMP-analysed zircons, and Tera-Wasserburg isochron plots from samples Bk1306, 1307 and 1308 from site 2 (Fig. 3), in the Lonnhöjden Mb of the Grythyttan Slate Fm. The EBS images show a faint oscillatory zonation. Scale bars are $20 \mu \mathrm{m}$. 

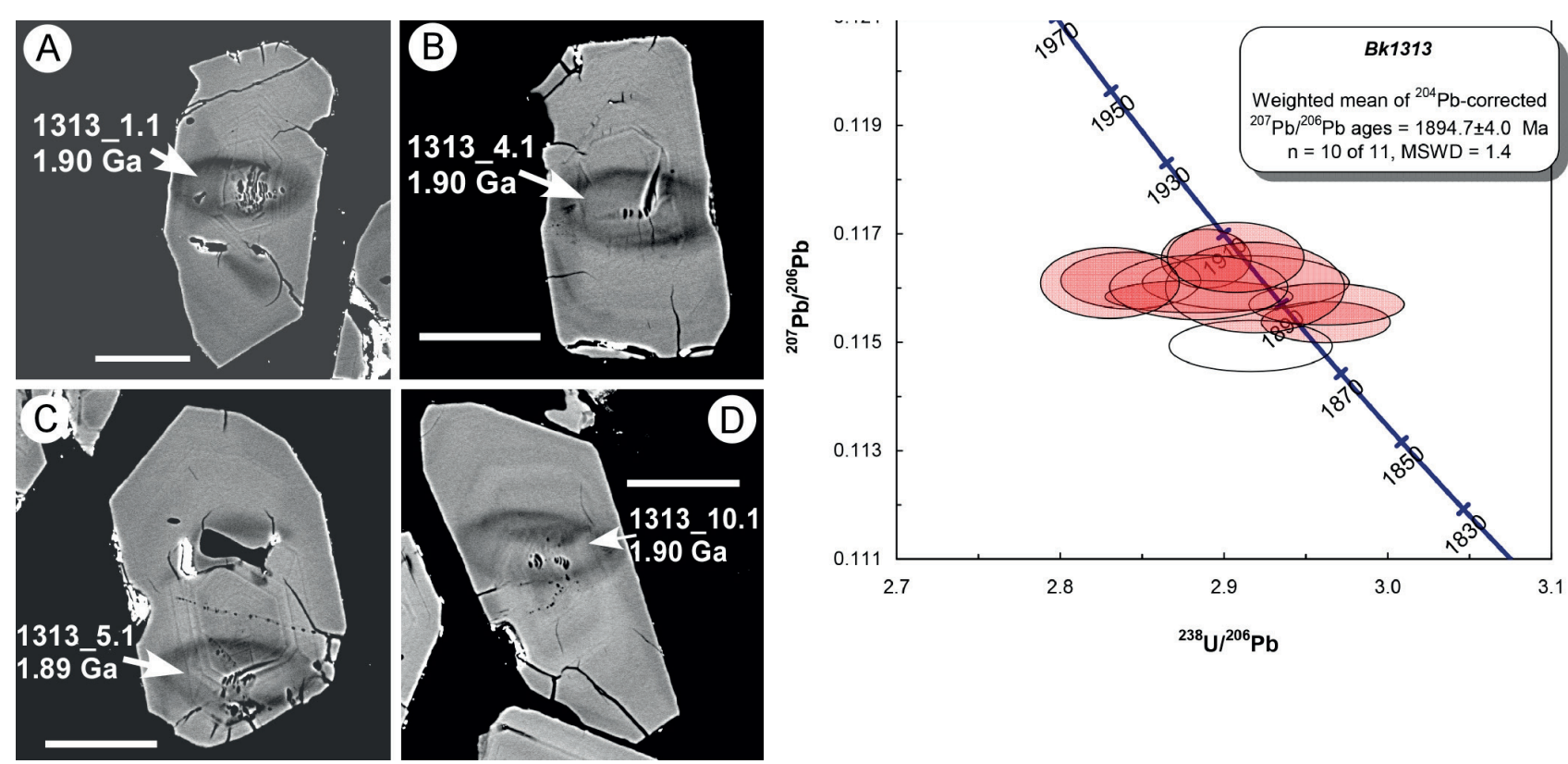

Figure 9. Selected EBS images (A)-(D) of SHRIMP-analysed zircons, and Tera-Wasserburg isochron plot from sample Bk1313 from site 3 (Fig. 3), in the Hällefors Mb of the Grythyttan Slate Fm. Scale bars are $20 \mu \mathrm{m}$.

the measured spots. From all three samples, sufficiently concordant $\mathrm{U}-\mathrm{Th}-\mathrm{Pb}$ isotopic results were collected. They are identical in age within error at c. $1895 \mathrm{Ma}$. The weighted mean ${ }^{207} \mathrm{~Pb} /{ }^{206} \mathrm{~Pb}$ age of sample Bk1307 (site 2, Figs. $3 \& 8$ ) could be taken as the most precise approximation of the depositional ages, at $1894.5 \pm 2.8$ Ma.

\section{Discussion}

Since Högbom (1910), the Grythyttan and Saxån slate belts have been interpreted as synclines filled with finegrained supracrustal formations. It is clear that Sundius (1923) a priori assumed that the slate belts represent a normal sedimentary sequence following an orogeny, whereby the conglomerates dated from the very end of this folding period and were interpreted as post-orogenic molasse. Subsequent authors, e.g., Magnusson (1970) and Lundström (1995a), followed this interpretation of the rocks and the stratigraphy, until Kuipers (1987) proved that the rocks of the slate belts are volcaniclastic sediments, and that the conglomerates on the west side of the Grythyttan Slate Belt are intraformational and not 'post-orogenic'. In our stratigraphy, the Torrvarpen conglomerates and other conglomerate lenses form the base of the Grythyttan Slate Formation and must therefore be derived from older rocks by subaerial or subglacial erosion, transported by alluvial streams, justifying a formation boundary for the Grythyttan Slate Formation at its base. Most of the surrounding rock types in the Bergslagen Group lack the thin-bedded distal turbidite character of the Grythyttan and Saxan slate belts.

Sundius (1923), and his successors, particularly at the Swedish Geological Survey (SGU, e.g., Lundström, 1987, and new SGU maps of the early 1990s) and in the Netherlands (e.g., Oen et al., 1982; Oen, 1987), were unaware of the volcaniclastic facies relationships in the volcanic-sedimentary successions as distinct from normal epiclastic facies. Before 1960, knowledge of the sedimentary nature of many Proterozoic ore deposits was limited at best, particularly so in the Bergslagen ore province. Input from sedimentary geology and its application to mining only became prominent in the last part of the twentieth century. In his thesis (Kuipers, 1987), the first author tried to make sense of the sedimentology, but failed to present a coherent structural-stratigraphic model involving both the Såxan and the Grythyttan basins. A recent model for the relationship between the slate belts and the surrounding metavolcanic rocks (in Beunk \& Kuipers, 2012) equally failed as a result of incorrect assumptions of stratigraphic and age relationships, and map scale structures. The model presented here makes previous models obsolete, due to 1) their lack of understanding of sedimentary environments, 2) structural blindspots, and 3) stratigraphic dependence on Högbom's and Sundius' century-old structural model.

Slate belts of limited size occur scattered within the Bergslagen Group of western Bergslagen (e.g., Stephens et al., 2007). The sedimentology of the Grythyttan Slate Belt and its restricted size is suggestive of a lacustrine depocentre in a volcanic back-arc or intra-arc setting, 


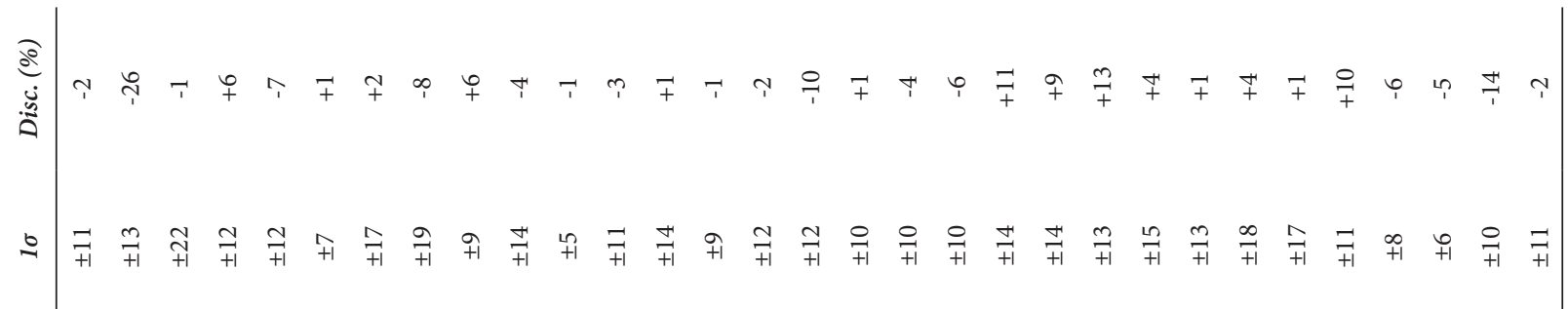

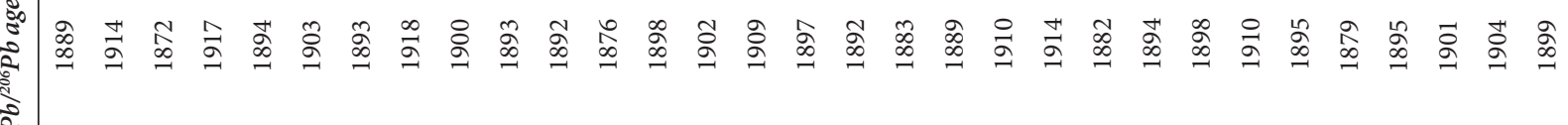
离

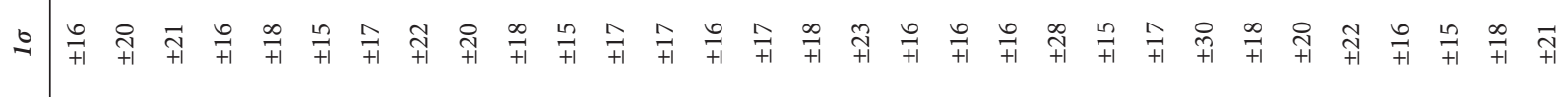

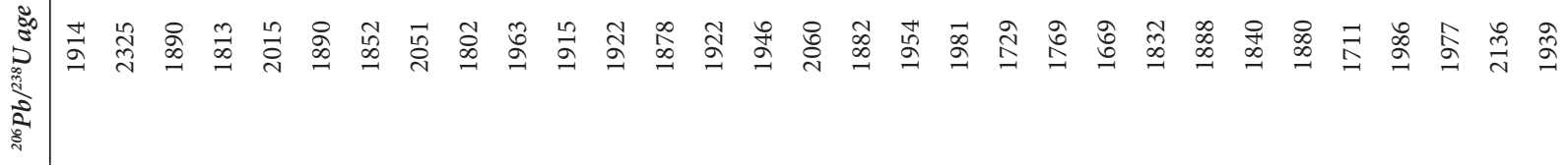

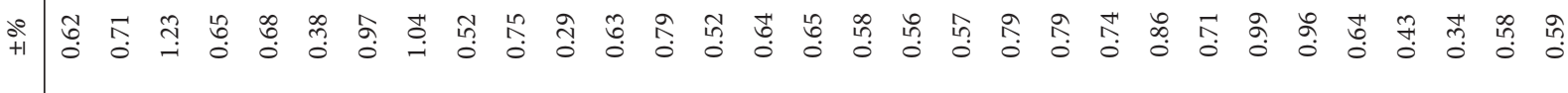

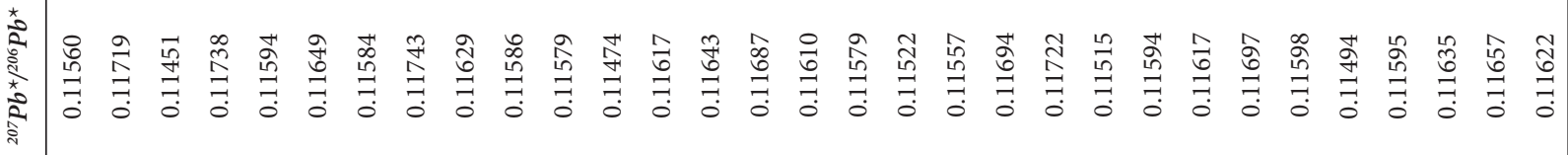

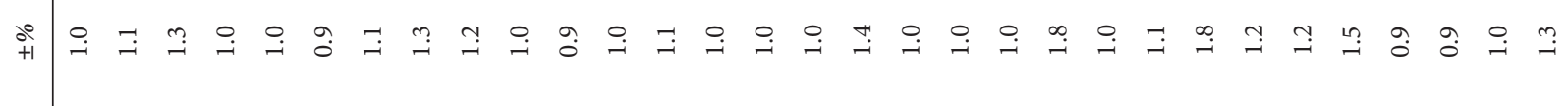

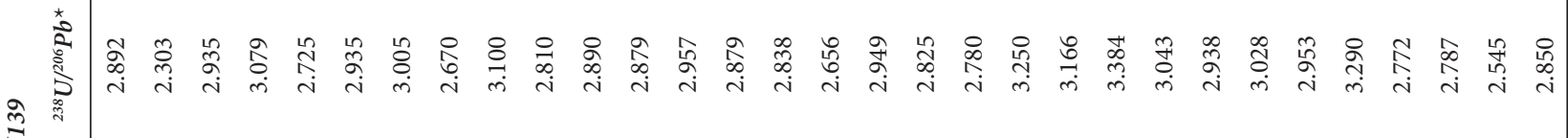

焉 要

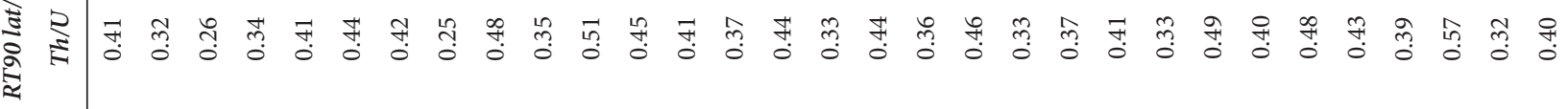

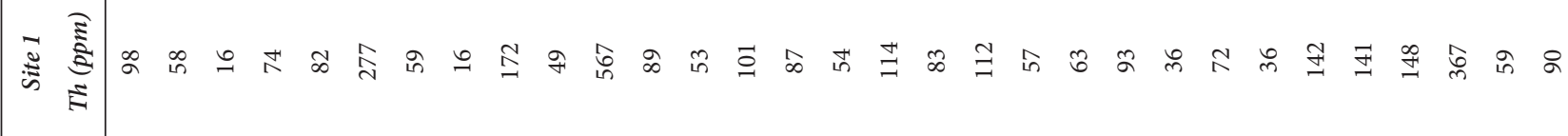

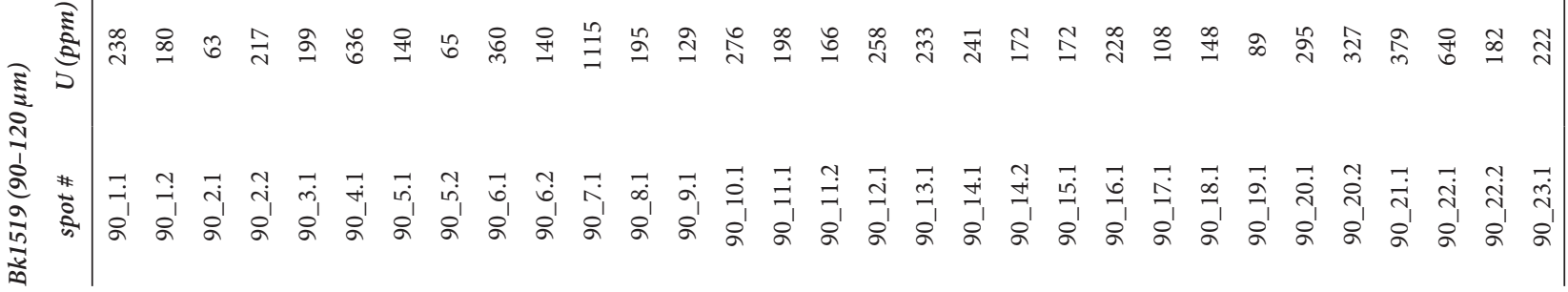




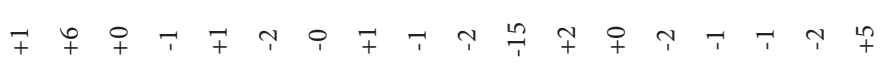

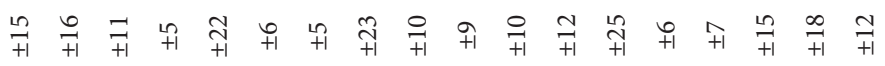

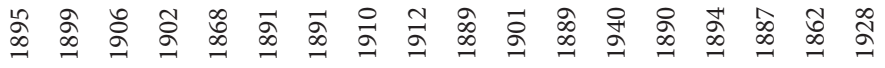

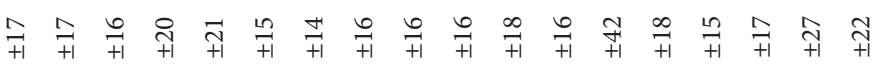

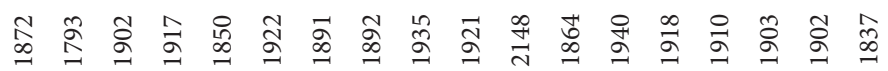

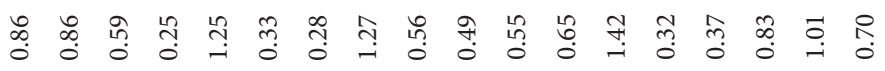

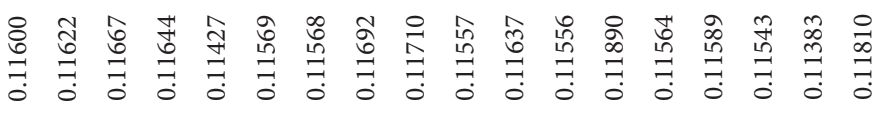

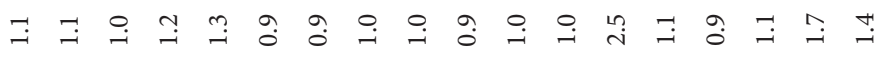

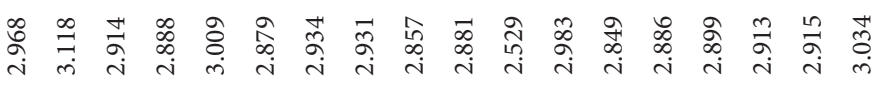

: :

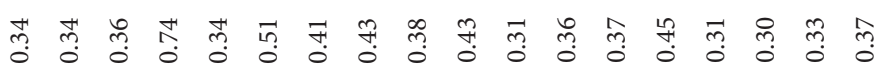

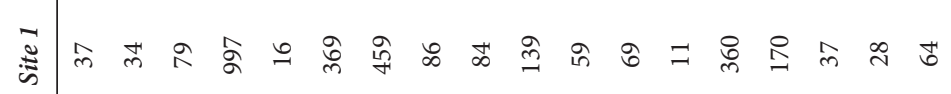

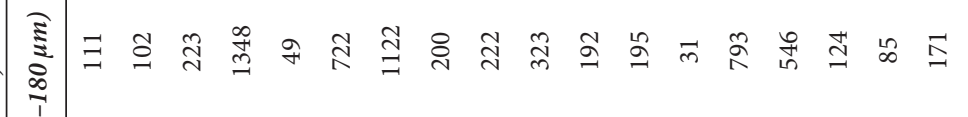

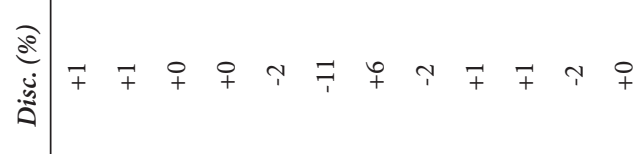

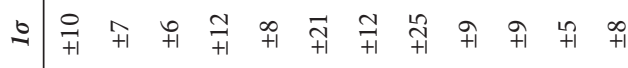

疍

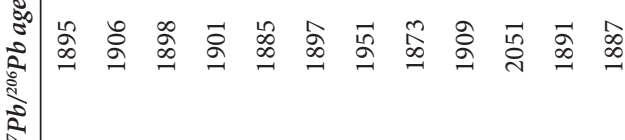

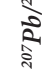

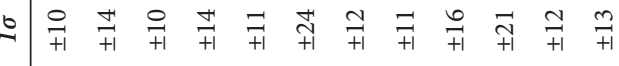

政

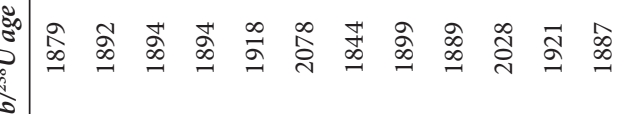

ถุํำ

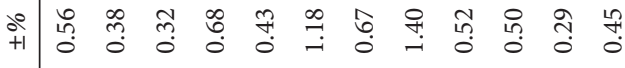

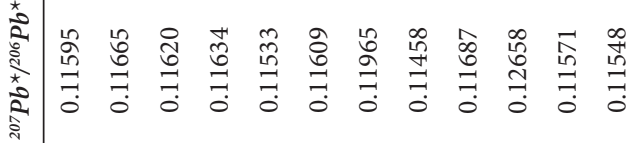

†ำ

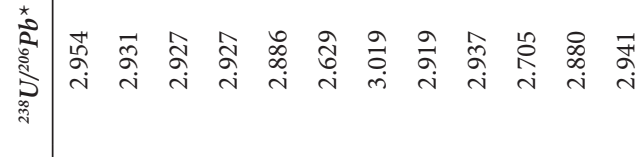

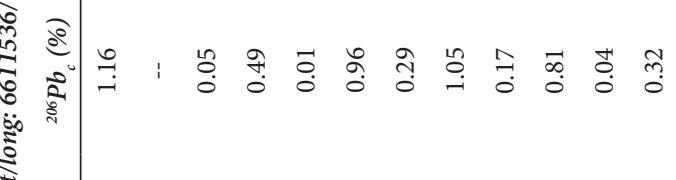

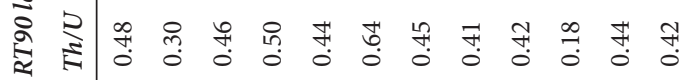

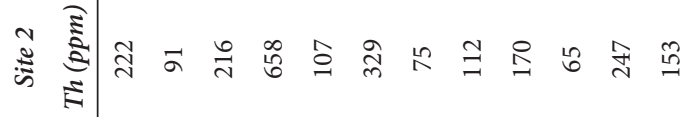

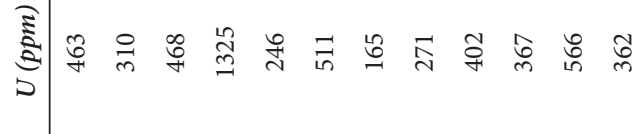
政

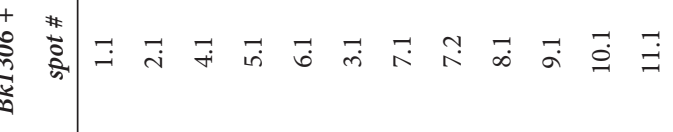




\begin{tabular}{|c|c|c|}
\hline 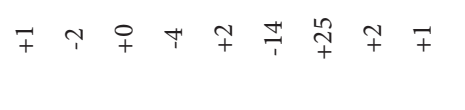 & & 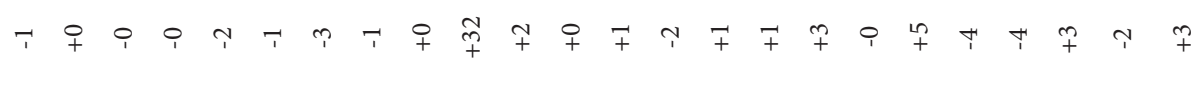 \\
\hline 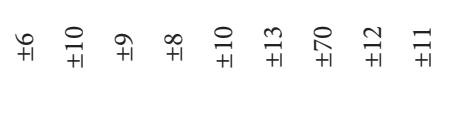 & & 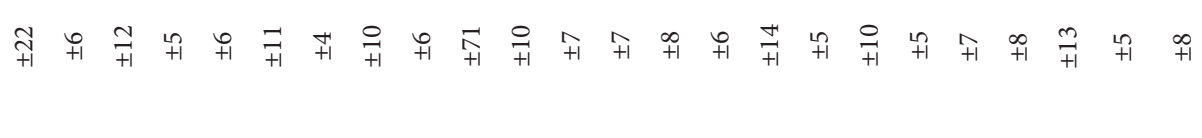 \\
\hline 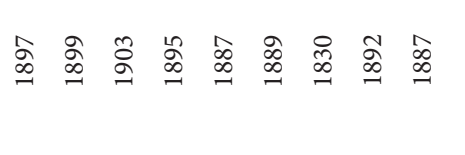 & & 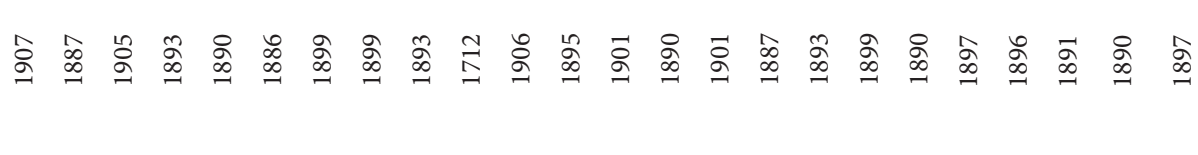 \\
\hline 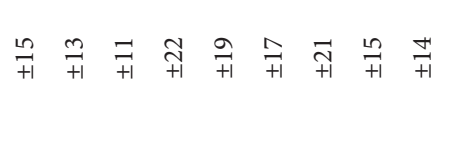 & & 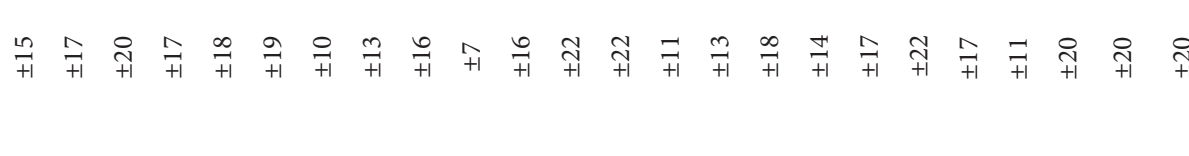 \\
\hline 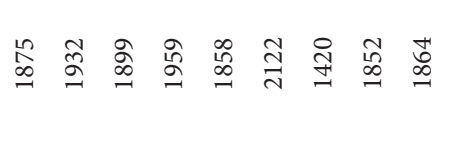 & & 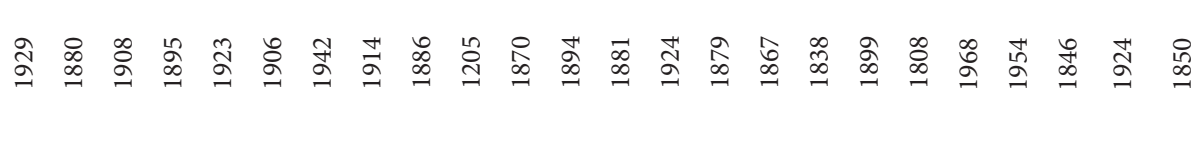 \\
\hline 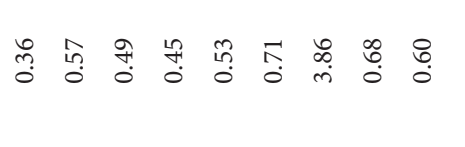 & & 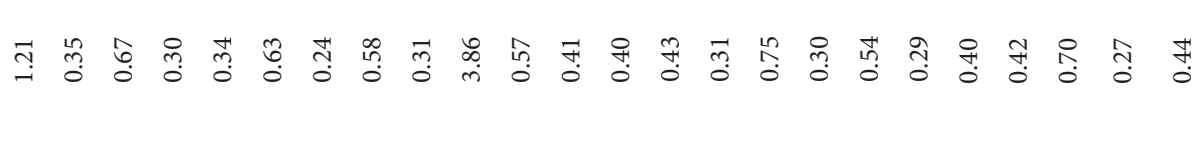 \\
\hline 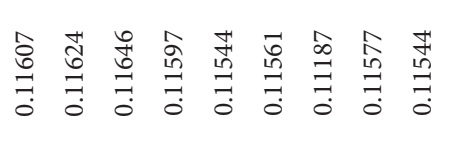 & & 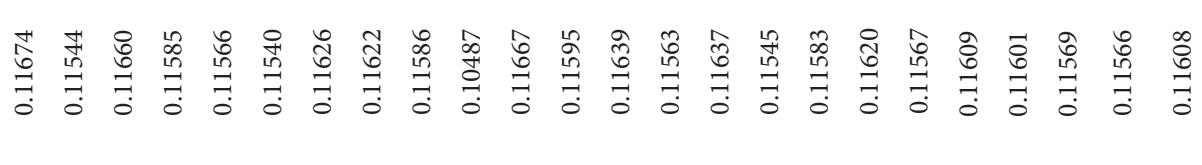 \\
\hline 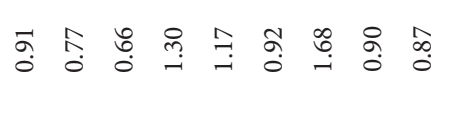 & & 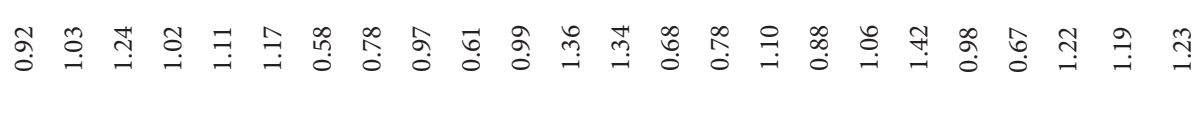 \\
\hline 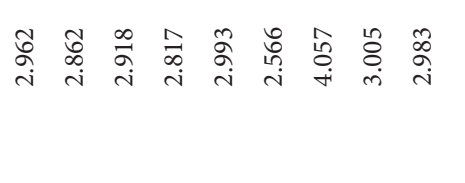 & 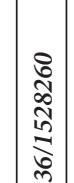 & 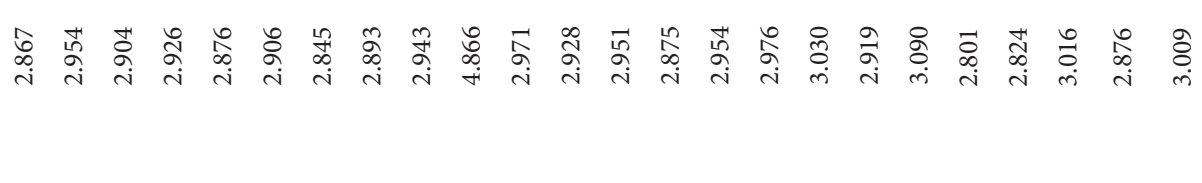 \\
\hline 虫 & 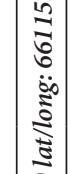 & 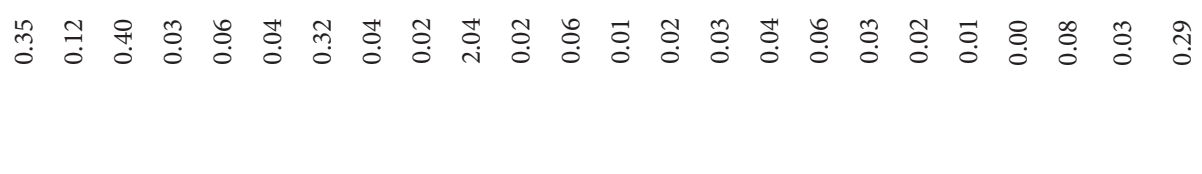 \\
\hline 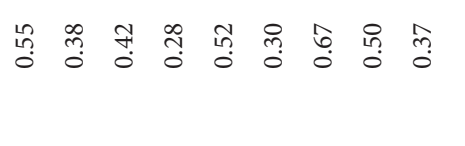 & : & 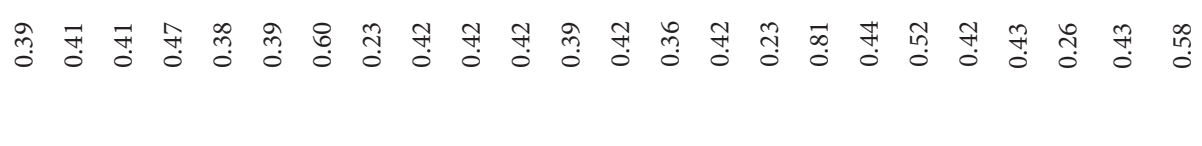 \\
\hline 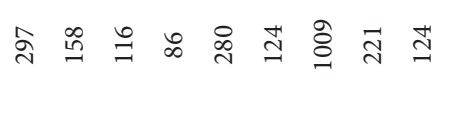 & $\tilde{\tilde{w}}$ & 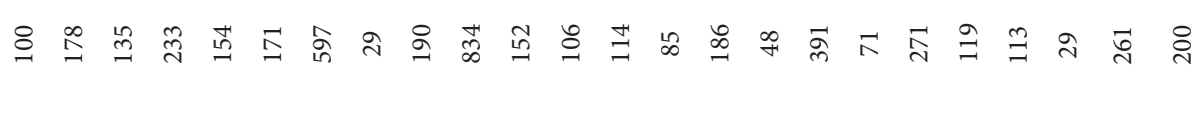 \\
\hline 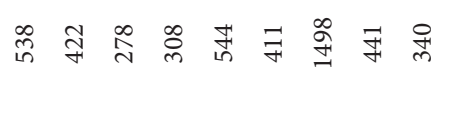 & & 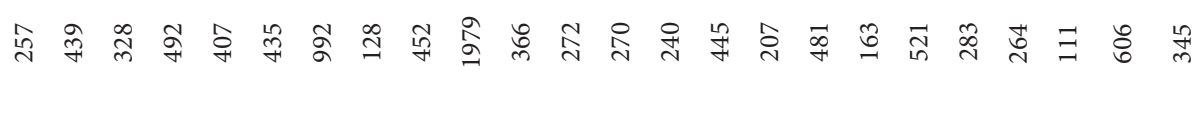 \\
\hline 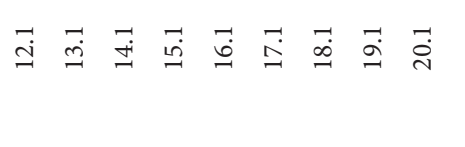 & $\mid$ & 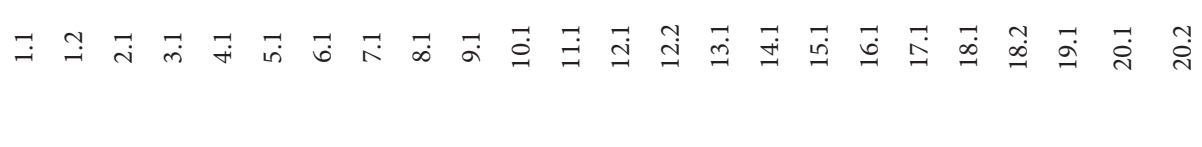 \\
\hline
\end{tabular}




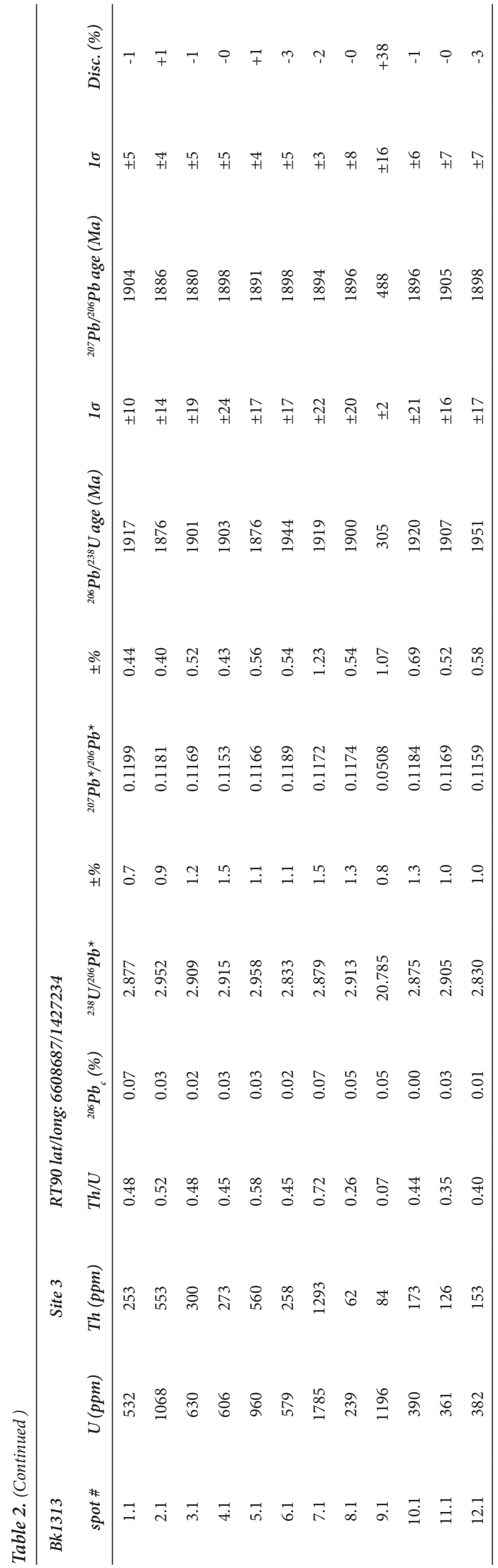

i.e., a crater or caldera lake. The distal facies (black slates) unit in the SSB is much thinner than in the GSB; therefore, the former has to have been closer to the rim of the caldera lake, and consequently the Grythyttan Slate Formation, with its greater overall thickness, probably accumulated in the central part of the lake. The main input of epiclastic debris came from the south in the shape of an alluvial fan. The caldera rim itself probably did not provide enough material to obscure the distal black slate facies occupying the lake away from the alluvial fan.

Significant hydrothermal activity affected the Saxån Slate Belt (Hellingwerf, 1986), which Sundius (1923) already envisaged as a lithostratigraphical equivalent to the Grythyttan Slate Belt. Hydrothermal alterations are a hallmark of the Bergslagen Group. Generally, seawater and hence a (shallow) marine environment is assumed as the source of the fluids (e.g., Baker \& De Groot, 1983; Hellingwerf, 1984; Hellingwerf \& Oen, 1986) which were responsible for widespread but strongly variable $\mathrm{Mg}$-metasomatism and $\mathrm{K} / \mathrm{Na}$ exchange in the Bergslagen Group. Terrestrial crater lakes exhibit an enormous variation in chemistries, some being just as magnesian as seawater (c. 1280 ppm; Varenkamp, 2015). Hence, hydrothermal alteration of volcanic crater lake bottoms may have occurred in places in the Bergslagen Group as well. The scattered, relatively small slate belts in western Bergslagen may support their common origin as isolated, possibly coeval caldera lakes and could indicate a stage of emergence of the Bergslagen Group above sea level. Despite the hydrothermal alterations in the SSB, these processes affected primarily the lower, marine members of the Bergslagen Group, like our Sångshyttan Formation (with stromatolitic limestones). These lower members, not the slate belts, host the BIFs and most of the hydrothermal VMS-type and skarn ores which made Bergslagen a classical Proterozoic ore province. Clear evidence of terrestrial conditions coeval with deposition of the (basal member of the) Grythyttan Slate Formation comes from the occurrence of cryoturbate sedimentary structures in volcaniclastic sediments near Kopparberg, some $30 \mathrm{kms}$ to the northeast of Grythyttan (Kuipers et al., 2013), which we have now dated as coeval within error with the Torrvarpen alluvial fan dated herein (Beunk et al., in prep.).

In all, a near-shore, partly marine, partly terrestrial setting would satisfy the various characteristics of the Bergslagen Group. The present-day Taupo volcanic backarc zone of the North Island of New Zealand equally grades northward from a terrestrial to a shallow-marine offshore setting towards the oceanic Havre trough backarc basin, and in our opinion serves as a modern analogue for Proterozoic Bergslagen. White Island in the Bay of Plenty off northern New Zealand, and the Santorini volcano of the Greek Cyclades are examples of shallowmarine calderas in comparable settings. We suggest that the two slate belts are the infilling of a single large 
caldera (originally some $60 \times 80 \mathrm{~km}$ ) with volcaniclastic and pelagic sediments, presently separated by a large anticline, with the Saxan Slate Belt as its western limb and the Grythyttan Slate Belt its eastern (Fig. 2, inset). The slates have been derived from proximal and medial facies volcaniclastics named sedimentary hälleflintas by Sundius (1923). However, the slates do not indicate the end of volcanism as suggested by Sundius (1923), but are merely an interlude in the supracrustal volcaniclastic Bergslagen Group and therefore not necessarily the youngest rocks of that group.

There appears to be no structural continuity across the fault zone bounding the Grythyttan Slate Belt along its eastern margin. Our present interpretation views the map-scale east-vergent folds to the west of the fault as the frontal part of an imbricate fan, thrust eastward against the palaeo-volcanoes of Hjulsjö and Sundsjö (Figs. 1 \& 2). The fan is likely underlain by a listric thrust fault (similar to the interpretation of Lundström, 1995b), which we interpret as an extensional, synsedimentary $D_{1}$ fault, rejuvenated by $\mathrm{D}_{2}$ thrusting and further deformed by Svecobaltic right-lateral $\mathrm{D}_{4}$ shearing.

Previously, Beunk \& Kuipers (2012) have interpreted the slate belts as incipient rift basins and precursors of $\mathrm{D}_{3}$ rifting of the Bergslagen microcontinent from its active continental margin, and suggested an age of 1860-1840 $\mathrm{Ma}$ for the origin of the slate belts. Our present zircon ages of $1895 \mathrm{Ma}$, as well as the revised stratigraphy, falsify that inference and confirm instead that the Torrvarpen alluvial fan in the southern Grythyttan Slate Belt, and, therefore, the basin as a whole, belongs to the 1.91$1.89 \mathrm{Ga}$ Bergslagen Group. This, and other elements of previous models for the Grythyttan Field recur in our revised model, viz. the anticlinorial connection between the GSB and the SSB (cf., Högbom, 1910; Sundius, 1923) and the relevance of early extensional (rift) faulting (cf., Oen, 1987; Beunk \& Kuipers, 2012). Yet, our interpretation of lithostratigraphic relationships within the long-studied GSB, and the tectonic, litho- and chronostratigraphic relations of the two slate belts to the surrounding Bergslagen Group metavolcanic rocks, as well as their palaeoenvironmental interpretation, is new and, hopefully, conclusive. The slate belts originated during late- $\mathrm{D}_{1}$ extensional back/intra-arc opening (cf., Beunk \& Kuipers, 2012) and are pre-orogenic with respect to the two main phases of Svecofennian orogenesis: (i) $\mathrm{D}_{2}$ closure of the back/intra-arc basin, which caused the east-vergent horizontal folding and thrusting described in this contribution, and (ii) $\mathrm{D}_{4}$ (Svecobaltic) oroclinal vertical folding and horizontal shearing. The isolated slate belts in western Bergslagen are unlike late- to post-orogenic (foreland) molasse basins as originally conceived for the GSB and SSB by Sundius (1923).

\section{Conclusions}

1) The lithostratigraphy of the Grythyttan Slate Belt reflects three-dimensional volcaniclastic facies associations as found in silicic-intermediate volcanic (back/intra) arc basins.

2) The Grythyttan Slate Formation likely represents a generally fining-upward sedimentary-volcaniclastic infilling of a large caldera lake (comparable to modern Lake Taupo in northern New Zealand), presently cropping out in two parallel, steeply dipping slate belts, the Grythyttan and Saxån slate belts, forming the limbs of a steep antiform.

3) The clast fabric of the Torrvarpen debris-flow conglomerates at the base of the lithostratigraphy of the Grythyttan Slate Formation was not formed by ductile deformation, as implicitly assumed in the study of Lisle et al. (1983), but results from sedimentary processes alone.

4) The Grythyttan Slate Formation is intraformational, forming an unique thin wedge of sediments between mainly felsic volcanic and volcaniclastic rocks representing a relatively short interlude followed by more felsic volcanics of the Bergslagen Group. A few other slate belts in western Bergslagen likely have an identical origin, but do not necessarily have to be time equivalent.

5) The present-day structure of the Grythyttan Field results from two successive phases of folding, affecting the entire Bergslagen Group: upright, horizontal $\mathrm{F}_{2}$ folds, refolded by vertical $\mathrm{F}_{4}$ folds. $\mathrm{F}_{2}$ reflects lateral shortening of the volcanic arc; $\mathrm{F}_{4}$ is a consequence of strike-slip shearing accompanying regional oroclinal bending, as previously identified by Beunk \& Kuipers (2012).

6) $\mathrm{F}_{2}$ deformed the Grythyttan Slate Formation into map-scale synclinoria and anticlinoria, similar but not identical to previous interpretations by Hogböm (1910), Sundius (1923) and Magnusson (1970). In particular, the Grythyttan Slate Belt is not equivalent to an inward younging synclinorium, but forms the eastern, eastward-younging limb of an overturned, east-vergent anticline, the axis of which is situated between the Grythyttan and Saxån slate belts.

7) $\mathrm{F}_{2}$ folding was accompanied by east-vergent thrusting of the Grythyttan Slate Belt, probably reactivating earlier extensional (listric) $\mathrm{D}_{1}$ faults. The resulting structure was likely an imbricate fan.

8) Deformation style was critically influenced by local structure and lithology: two former granite-cored volcanoes resisted folding and appear to have acted 
as the frontal ramp of the east-vergent $\mathrm{D}_{2}$ imbricate fan.

9) The two volcanoes also determined the location of disharmonic thickening of the slaty hinge of the mapscale vertical $\mathrm{F}_{4}$ fold forming the $\mathrm{Z}$-shaped eastern margin of the Grythyttan Slate Belt.

10) The Torrvarpen conglomerate was dated by U-Pb SIMS geochronology of zircons from bracketing silicic volcanics, at $1895 \mathrm{Ma}$, demonstrating that the Grythyttan Slate Belt belongs entirely to the preorogenic, 1.91-1.89 Ga Bergslagen Group.

Acknowledgements. We gratefully acknowledge generous support for fieldwork and analytical costs by the Dr. Schürmann Foundation for Dutch Precambrian Research (www.dr-schurmannfonds.nl). We are indebted to Sergei Matveev for chlorite EPMA analyses at Vrije Universiteit, Amsterdam, and to Hanco Zwaan for access to the Raman microprobe at the Naturalis Biodiversity Center, Leiden. The Swedish Geological Survey (SGU) provided aerial photographs of part of the Grythyttan Field. We acknowledge Drs. Bernard Bingen (NGU) and Stefan Luth (SGU), and an anonymous reviewer as well as journal editor Trond Slagstad for helpful and detailed suggestions for improvement of earlier versions of the manuscript.

\section{References}

Allen, R.L., Lundström, I., Ripa, M., Simeonov, A. \& Christofferson, H. 1996: Facies analysis of a $1.9 \mathrm{Ga}$, continental margin, back-arc, felsic caldera province with diverse $\mathrm{Zn}-\mathrm{Pb}-\mathrm{Ag}-(\mathrm{Cu}-\mathrm{Au})$ sulfide and Fe oxide deposits, Bergslagen Region, Sweden. Economic Geology 91, 979-1008. https://doi.org/10.2113/gsecongeo.91.6.979.

Baker, J.H. \& De Groot, P.A. 1983: Proterozoic seawater - felsic volcanics interaction W. Bergslagen, Sweden. Evidence for high REE mobility and implications for 1.8 Ga seawater compositions. Contributions to Mineralogy and Petrology 82, 119-130. https://doi.org/10.1007/BF01166607.

Beunk, F.F. \& Kuipers, G. 2012: The Bergslagen ore province, Sweden: Review and update of an accreted orocline, 1.9-1.8 Ga BP. Precambrian Research 216-219, 95-119. https://doi.org/10.1016/j.precamres.2012.05.007.

Beunk, F.F. \& Valbracht, P.J. 1991: Early Proterozoic continental tholeiites from western Bergslagen, Central Sweden: III. Geodynamic inferences. Precambrian Research 52, 231-243. https://doi.org/10.1016/0301-9268(91)90082-L.

Björk, L. 1983: Bergsgrundskartan 11E Filipstad NV, scale 1:50,000, series AF, nr. 147, Sveriges Geologiska Undersökning.

Boekschoten, G.J., Van der Raad, A.C., Kenter, J.A.M. \& Reijmer, J.J.G. 1988: Note on a mid-Proterozoic stromatolite limestone, South of Grythyttan, Bergslagen, Sweden. Geologie en Mijnbouw (Netherlands Journal of Geoscience) 67, 467-469.

Bouma, A.H. 1962: Sedimentology of some Flysch deposits: A graphic approach to facies interpretation. Elsevier, Amsterdam, $168 \mathrm{pp}$.

Cho, M., Cheong, W., Ernst, W.G., Yi, K. \& Kim, J. 2013: SHRIMP U-Pb ages of detrital zircons in metasedimentary rocks of the central Ogcheon fold-thrust belt, Korea: evidence for tectonic assembly of Paleozoic sedimentary protoliths. Journal of Asian Earth Science 63, 234-249. https://doi.org/10.1016/j.jseaes.2012.08.020.
Damman, A.H. 1989: Skarn and ore formation in the Gåsborn Area, West Bergslagen, central Sweden: a study of (sub)seafloor hydrothermal-metamorphic mineral assemblages. $\mathrm{PhD}$ thesis, Vrije Universiteit Amsterdam, 183 pp.

Enos, P. 1977: Flow regimes in debris flow. Sedimentology 24, 133-142. https://doi.org/10.1111/j.1365-3091.1977.tb00123.x.

Frietsch, R. 1975: Brief outline of the metallic mineral resources of Sweden. Sveriges Geologiska Undersökning C718, 1-64.

Hellingwerf, R.H. 1984: Paragenetic Zoning and Genesis of Cu-ZnFe-Pb-As Sulfide Skarn Ores in a Proterozoic Rift Basin, Gruvåsen, Western Bergslagen, Sweden. Economic Geology 79, 696-715. https://doi.org/10.2113/gsecongeo.79.4.696.

Hellingwerf, R.H. 1986: Contributions to the geology and ore genesis of western Bergslagen, Sweden. PhD thesis, GUA Papers of Geology 1, $260 \mathrm{pp}$.

Hellingwerf, R.H. 1987: Formation of sulphide deposits and its relation to sodic and potassic alteration of Proterozoic metabasites in the Saxå rift basin, Bergslagen, Sweden. Mineralium Deposita 22, 53-63. https://doi.org/10.1007/BF00204245.

Hellingwerf, R.H. \& Oen, I.S. 1986: Some geochemical aspects of altered and less altered metabasic rocks in the Saxå area, Bergslagen, Sweden. Neues Jahrbuch für Mineralogie, Monatshefte 2, 65-81.

Hermansson, T., Stephens, M.B., Corfu, F., Page, L.M. \& Andersson, J. 2008: Migratory tectonic switching, western Svecofennian orogen, central Sweden: Constraints from $\mathrm{U} / \mathrm{Pb}$ zircon and titanite geochronology. Precambrian Research 161, 250-278. https://doi.org/10.1016/j.precamres.2007.08.008.

Högbom, A.G. 1910: Precambrian geology of Sweden. Bulletin of the Geological Institution of the University of Uppsala 10, 1-80.

Jasiński, A.W., Baker, J.H. \& de Groot, P. 1988: Thermodynamic aspects of the Mg-chlorite - alkali feldspar - sericite - kaolinite system: Applications to the fossil sub-seafloor hydrothermal system at Hjulsjö, Bergslagen, Sweden. GUA Papers of Geology 1, 159-188.

Korja, A., Lahtinen, R. \& Nironen, M. 2006: The Svecofennian orogen: a collage of microcontinents and island arcs. In Gee, D.G. \& Stephenson, R.A. (eds.): European Lithosphere Dynamics, Memoirs of the Geological Society of London 32, pp. 561-578. https://doi.org/10.1144/GSL.MEM.2006.032.01.34.

Kuipers, G. 1987: Volcaniclastic facies associations in the MidProterozoic Grythyttan rift-basin and their lithostratigraphic relationship, West-Bergslagen, Central Sweden. PhD thesis, GUA Papers of Geology 1, 162 pp.

Kuipers, G. \& Beunk, F.F. 2014: The Proterozoic (1.85 Ga) Älvestorp Conglomerate, Bergslagen, Central Sweden. Geology Today 30, 222226. https://doi.org/10.1111/gto.12077.

Kuipers, G., Beunk, F.F. \& van der Wateren, F.M. 2013: Periglacial evidence for a 1.91-1.89 Ga old glacial period at low latitude, Central Sweden. Geology Today 29, 218-221. https://doi.org/10.1111/gto.12027.

Lahtinen, R., Korja, A. \& Nironen, M. 2005: Palaeoproterozoic tectonic evolution. In Lehtinen, M., Nurmi, P.A. \& Rämö, O.T. (eds.): Precambrian Geology of Finland - Key to the Evolution of the Fennoscandian Shield, Elsevier B.V., Amsterdam, pp. 481-532. https://doi.org/10.1016/S0166-2635(05)80012-X.

Lisle, R., Rondeel, H.E., Doorn, D., Brugge, J. \& van der Gaag, P. 1983: Estimation of viscosity contrast and finite strain from deformed elliptical inclusions. Journal of Structural Geology 5, 603-609. https://doi.org/10.1016/0191-8141(83)90072-X.

Lundegård, P.H. \& Bygghammar, B. 1987: Bergsgrundskartan 11E Filipstad SV, scale 1:50.000, series AF, nr. 157, Sveriges Geologiska Undersökning.

Lundström, I. 1987: Lateral variations in supracrustal geology within the Swedish part of the southern Svecokarelian volcanic belt. Precambrian Research 35, 353-365. https://doi.org/10.1016/0301-9268(87)90063-5.

Lundström, I. 1995a: Beskrivning till berggrundskartorna Filipstad SO och NO. Sveriges Geologiska Undersökning, series AF, nr. 177 \& 185. 
Lundström, I. 1995b: Berggrundskartan 11E Filipstad NO, scale 1:50,000, series AF, nr. 185, Sveriges Geologiska Undersökning.

Magnusson, N.H. 1970: The origin of the iron ores in central Sweden and the history of their alterations. Sveriges Geologiska Undersökning $643,1-127$.

Major, J.J. 1997: Depositional processes in large-scale debris-flow experiments. Journal of Geology 105, 345-366. https://doi.org/10.1086/515930.

Major, J.J. 1998: Pebble orientation on large, experimental debris-flow deposits. Sedimentary Geology 117, 151-164. https://doi.org/10.1016/S0037-0738(98)00014-1.

Oen, I.S. 1987: Rift-related igneous activity and metallogenesis in SW Bergslagen, Sweden. Precambrian Research 35, 367-382. https://doi.org/10.1016/0301-9268(87)90064-7.

Oen, I.S., Helmers, H., Verschure, R.H. \& Wiklander, U. 1982: Ore deposition in a Proterozoic incipient rift zone environment: a tentative model for the Filipstad-Grythyttan-Hjulsjö region, Bergslagen, Sweden. Geologische Rundschau 71, 182-194. https://doi.org/10.1007/BF01825035.

Oen, I.S., de Maesschalk, A.A. \& Lustenhouwer, W.J. 1986: MidProterozoic exhalative-sedimentary Mn-skarns containing possible microbial fossils, Grythyttan, Bergslagen, Sweden. Economic Geology 81, 1533-1543.

https://doi.org/10.2113/gsecongeo.81.6.1533.

Paces, J.B. \& Miller, J.D. 1993: Precise U-Pb ages of Duluth Complex and related mafic intrusions, northeastern Minnesota: geochronological insights to physical, petrogenetic, paleomagnetic, and tectonomagmatic processes associated with the $1.1 \mathrm{Ga}$ midcontinent rift system. Journal of Geophysical Research 98, 13997-14013. https://doi.org/10.1029/93JB01159.

Passchier, C.W. \& Trouw, R.A.J. 2005: Microtectonics. $2^{\text {nd }}$ Ed., Springer, $366 \mathrm{pp}$.

Pettijohn, F.J. 1975: Sedimentary rocks. $3^{\text {rd }}$ Ed., Springer, 628 pp.

Schmincke, H.U. \& Swanson, D.L. 1967: Laminar viscous flowage structures in ash flow tuffs from Gran Canaria, Canary Islands. Journal of Geology 75, 641-664. https://doi.org/10.1086/627292.

Stephens, M.B., Ahl, M., Bergman, T., Lundström, I., Persson, L., Ripa, M. \& Wahlgren, C.H. 2007: Regional geological and geophysical maps of Bergslagen and surrounding areas: Bedrock map, mineral resources map, metamorphic, structural and isotope age map. Sveriges Geologiska Undersökning, Ba 58.

Stephens, M.B., Ripa, M., Lundström, I., Persson, L., Bergman, T., Ahl, M., Wahlgren, C.H., Persson, P.O. \& Wikström, L. 2009: Synthesis of the bedrock geology in the Bergslagen region, Fennoscandian Shield, south-central Sweden. Sveriges Geologiska Undersökning, Ba 58, $259 \mathrm{pp}$.

Sundius, N. 1923: Grythyttefältets geologi. Sveriges Geologiska Undersökning Serie C 312, 353 pp.

Van der Velden, W., Baker, J., de Maesschalk, S. \& van Meerten, T. 1982: Bimodal early Proterozoic volcanism in the Grythytte field and associated volcano-plutonic complexes, Bergslagen, Central Sweden. Geologische Rundschau 71, 171-181. https://doi.org/10.1007/BF01825034.

Van Meerten, T. 1988: Lithostratigraphic correlations in an asymmetrical rift-basin: the Grythyttan area, W. Bergslagen, Sweden. Netherlands Journal of Geoscience 67, 203-212.

Varenkamp, J.C. 2015: The Chemical Composition and Evolution of Volcanic Lakes. In Rouwet, D., Christenson, B., Tassi, F. \& Vandemeulebrouck, J. (eds): Volcanic Lakes, Advances in Volcanology, Springer, Berlin, Heidelberg, 93-123.

Wahlgren, C.H. \& Stephens, M.D. 1990: Post-Svecofennian plastic and brittle-plastic shear zones in westernmost Bergslagen, Sweden. GFF 112, 204-205. https://doi.org/10.1080/11035899009453198.

Wiklander, U. \& Lundström, I. 1991: Berggrundskartan 11E Filipstad SO, scale 1:50,000, series AF, nr. 177, Sveriges Geologiska Undersökning. 